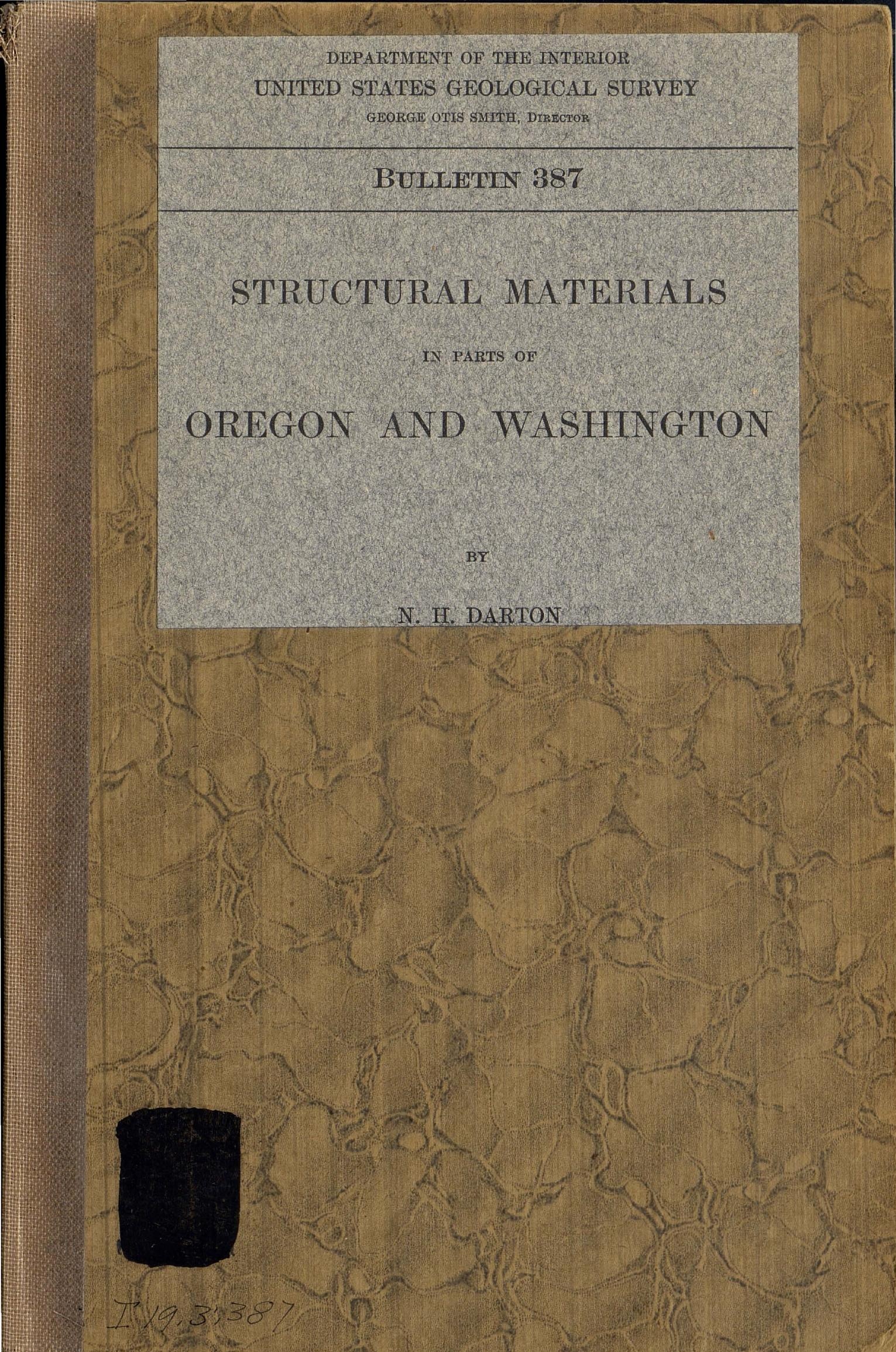


TEXAS TECH UNIVERSITY

31295013466122 


$$
A D D-9131
$$

DEPARTMENT OF THE INTERIOR

UNITED STATES GEOLOGICAL SURVEY

GEORGE OTIS SMITH, DIRECTOR

BULLETIN 387

\section{STRUCTURAL MATERIALS}

IN PARTS OF

\section{OREGON AND WASHINGTON}

BY

N. H. DARTON

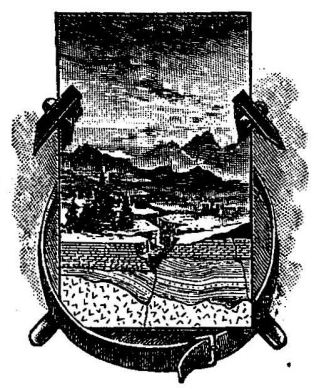

WASHINGTON

GOVERNMENT PRINTING OFFICE

$1909_{\text {LIBRARY }}$

TEXAS TECHNOLOGICAL COLLEGE LUBBOCK, TEXAS 



\section{CONTENTS.}

Introduction.

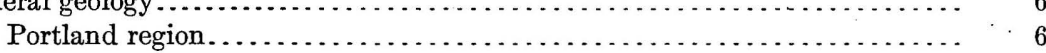

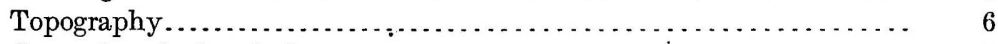

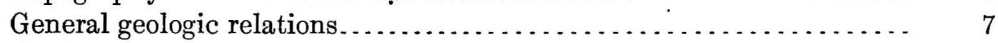

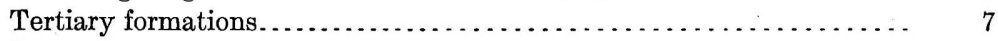

Igneous rocks.......................................... 8

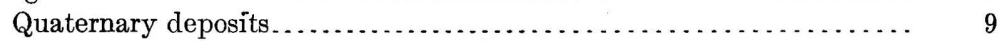

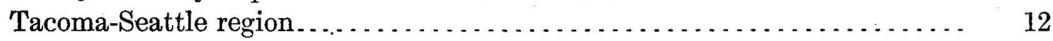

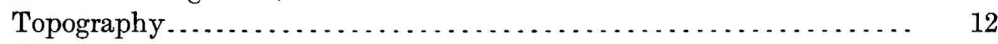

Older rocks........................................ 12

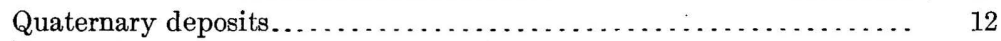

Structural materials........................................... 13

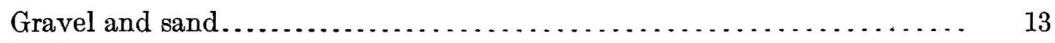

Broken rock................................................ 16

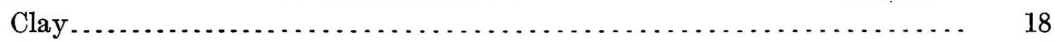

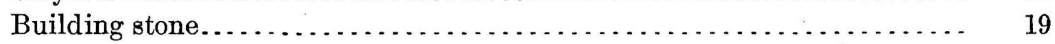

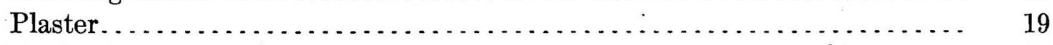

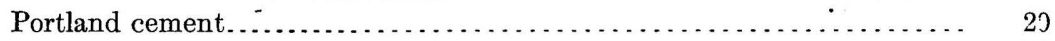

Cement materials in Washington................................ 21

San Juan County......................................... 21

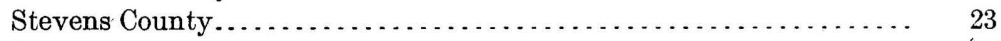

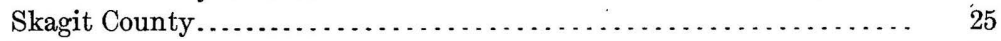

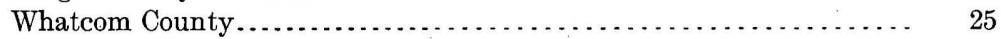

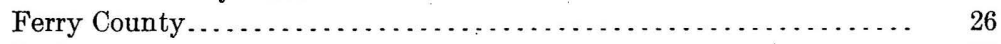

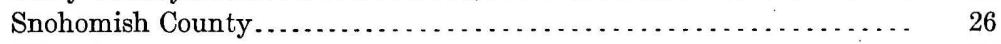

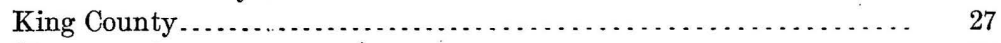

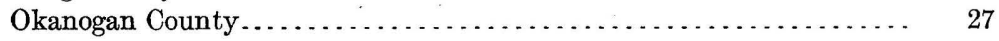

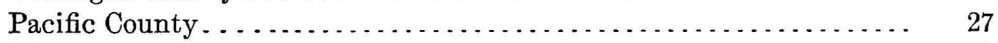

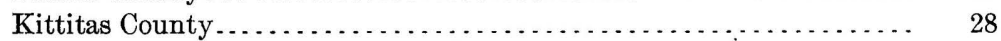

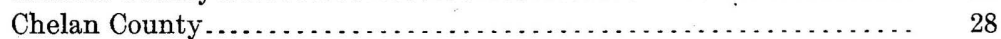

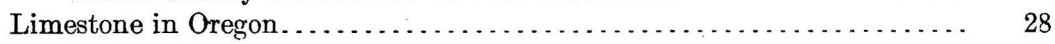

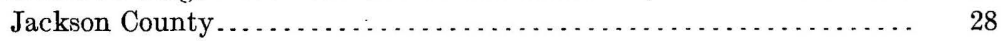

Josephine County . . . . . . . . . . . . . . . . . . . . . . . . . . $\quad 29$

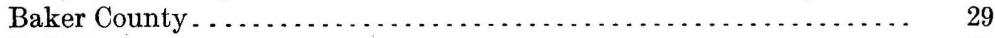

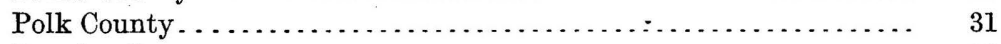

Douglas County ...................................... $\quad 32$

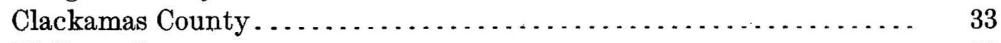

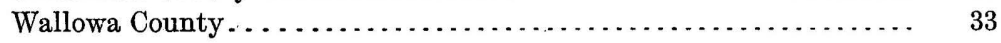




\section{ILLUSTRATIONS.}

Plate I. Map of Portland, Oreg., and vicinity, showing distribution of structural materials......................................

II. Dredge used for raising concrete gravel from bed of Willamette River at Portland, Oreg . . . . .............................. 14

III. $A$, River gravel and sand, east bank Willamette River, Portland, Oreg.; $B$, gravel on Cornell road in northwest part of Portland,

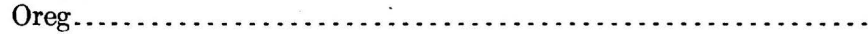

IV. $A$, Lower quarry near St. Helens, Oreg.; $B$, gravel and sand on east bank of Willamette River, Portland, Oreg..................

V. $A$, Gravel pit in southern part of Tacoma, Wash.; $B$, gravel pit on Bellevue Avenue near Pike street, Seattle, Wash................

Page.

VI. Temporary gravel and sand pit with screen, washer, and bin, Boren avenue near Pike street, Seattle, Wash.....................

VII. $A$, Upper quarry, crusher, and loading incline south bank of Columbia River near St. Helens, Oreg.; $B$, quarry near Fishers Landing, Columbia River, Washington.........................

VIII. $A$, Clay pit at Russell Landing, 4 miles above Vancouver, Wash.; $B$, gravel pit, screens, washer, and bins, Steilacoom, Wash..... 22

IX. Map of Washington and Oregon, showing distribution of limestone... 28

Figure 1. East-west section through Portland, Oreg. ................ 6 


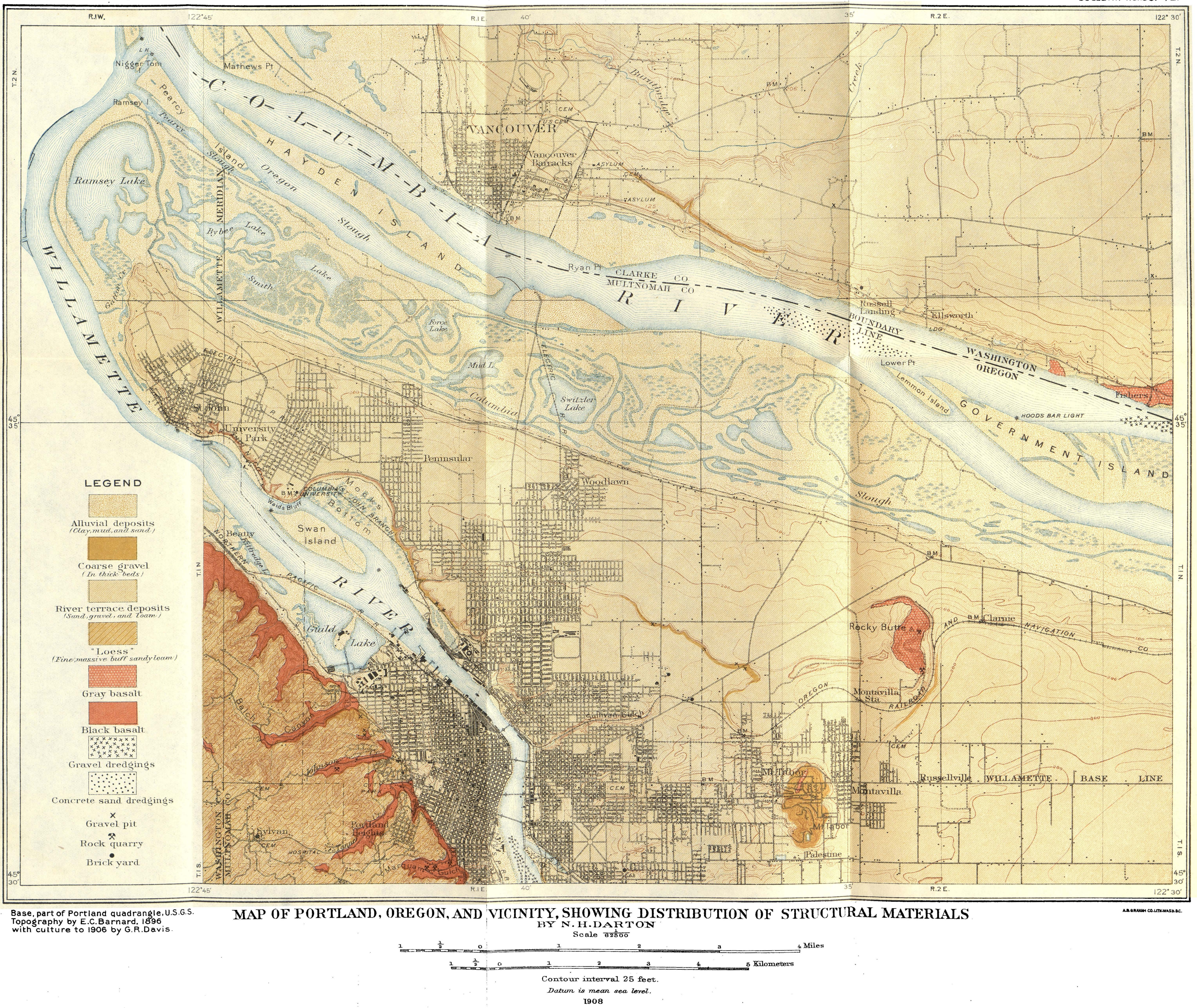




\title{
STRUCTURAL MATERIALS IN PARTS OF OREGON AND WASHINGTON.
}

\author{
By N. H. Darton.
}

\section{INTRODUCTION:}

The rapid growth of cities in Oregon and. Washington has caused great demand in these States for structural materials of all kinds, and although some of these materials are locally abundant and satisfactory others have to be brought from great distances. Common bricks, which form the principal component of most buildings, are made in the vicinity of all the cities, even within the city limits, and the supply of suitable loam is very great. Gravel and sand for concrete and sand for mortar are obtained in large quantities in the immediate vicinity of the cities. Cement, however, which is so extensively used in concrete, is produced at only one place in the two States, and most of that used is brought from distant points, much of it being imported from England, Germany, Belgium, and Japan. Building stones are hauled many miles, especially the kinds used for interior decorations, most of which are shipped across the continent. Highclass brick, terra cotta, lime, plaster, and many other building materials used in this region are produced at distant places.

Yet the cost of most supplies that are now brought from distant places can be reduced by utilizing the local resources of Washington and Oregon. Limestone is available in ample supply for cement manufacture; building stones, even to finest marbles, exist in some of the mountains, and extensive deposits of clay, sands, and other building materials occur at many localities near the coast.

The investigation on which this report is based was intended mainly to ascertain the local resources of the gravel, sand, and crushed rock used in concrete in Portland, Seattle, and Tacoma. Representative samples of these materials were also obtained to be tested in the St. Louis laboratories of the United States Geological Survey. Considerable attention was given to the occurrence of limestone suitable for the manufacture of cement, and many localities were visited in that connection. The building stones of Washington have been treated extensively in a report by Prof. Solon Shedd, published by the State Geological Survey. The demand for building 


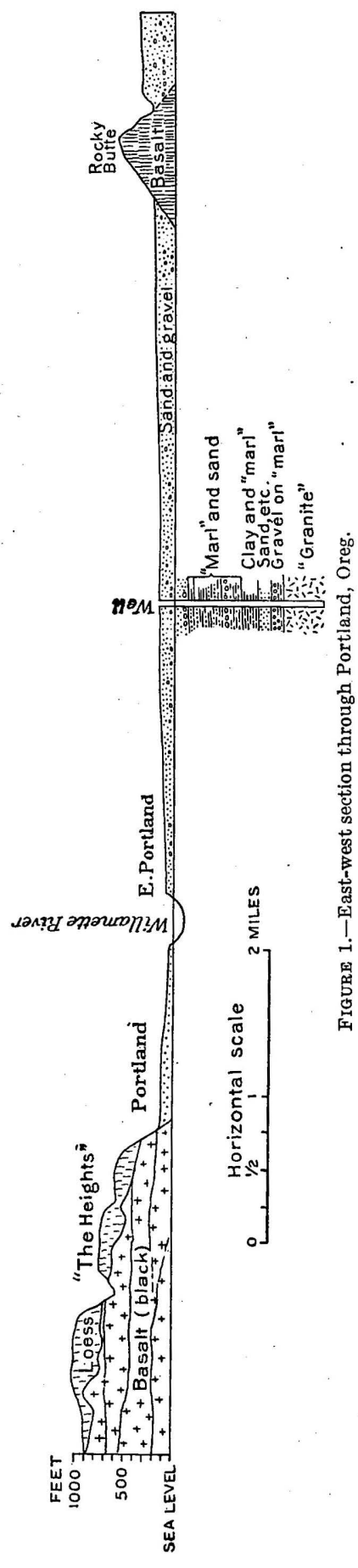

materials in the Northwest is well indicated by the fact that in 1906 building operations in Seattle represented an expenditure of $\$ 11,920,438$ for labor and materials and in 1907 an expenditure of $\$ 13,577,700$. In Portland the amount in 1906 was $\$ 6,927,971$ and in 1907 it increaséd to $\$ 9,446,982$.

The following publications give information regarding building materials available in the region treated in this report: Ann. Rept. Washington Geol. Survey, vol. 1, 1901; vol. 2, 1902. The latter includes a report on building stone by $\mathrm{S}$. Shedd. Geol. Atlas U. S., Tacoma folio (No. 54), by B. Willis and G. O. Smith; Ellensburg folio (No. 86), by G. O. Smith and F. C. Calkins; Mount Stuart folio (No. 106), by G. O. Smith; Roseburg folio (No. 49), by J. S. Diller; Coos Bay folio (No. 73), by J. S. Diller.

\section{GENERAL GEOLOGY.}

PORTLAND REGION.

Topography.-Portland is built on the terraces and hill slopes on both sides of Willamette River, about 12 miles above the confluence of that river with the Columbia. The terraces rise in gradual succession to an altitude of slightly over 100 feet above sea level on the west side of the river and to 300 feet in the outlying suburbs on the east. North of the city the highest terrace constitutes a ridge separating the valley of the Willamette from the low flats on the south side of Columbia River. This ridge, known as the peninsula, has an altitude of 100 feet at its western end and rises gradually to the east. The terraces on the west side of the Willamette are less than 2 miles wide in Portland: They rise gradually to the west in a succession of long slopes and 
several terrace scarps which are extensively masked by the grading and filling of the city. They are abruptly terminated on the west by steep slopes, rising into a high ridge with numerous summits over 1,000 feet in altitude. The main rise follows a remarkably straight course, trending due northwest. The ridge is cut by numerous canyons which in places have precipitous walls. These canyons break the highland into irregular ridges with steep slopes but rounded summits.

From the wide terraces east of Portland rise a line of high, detached knobs known as Rocky Butte, Mount Tabor, Kelly Butte, and Mount Scott. The altitude of these above the surrounding plains is from 300 to 400 feet, and they are separated by wide, flat-bottomed gaps at the level of the general terrace surface.

General geologic relations.-The extensive terraces about Portland consist of gravel and sand of Quaternary age, deposited by Columbia and Willamette rivers. These lie in a wide trough excavated in rocks of later Tertiary age, in part volcanic. The high ridge west of Portland consists of dark basalt, extensively covered by a loesslike silt and local gravel deposits. The general relations are shown in the accompanying cross section (fig. 1).

Tertiary formations.- -None of the older sedimentary rocks appear to be exposed in the vicinity of Portland, but it is probable that the entire region is underlain by them. The record of a well on the Ladd farm, in the SE. $\frac{1}{4}$ NE. $\frac{1}{4}$ sec. 36 , in East Portland, is reported by W.S. Everett as follows:

Record of well on Ladd farm, East Portland, Oreg.

\begin{tabular}{|c|c|}
\hline Loam and sand . & $\begin{array}{l}\text { Feet. } \\
0-\quad 100\end{array}$ \\
\hline ind, clay, and gravel. . . & $100-120$ \\
\hline and with bowlders of granite and basalt ........ & $120-140$ \\
\hline Bowlders, gravel, and sand $\ldots \ldots \ldots \ldots \ldots \ldots \ldots$ & $140-220$ \\
\hline Coarse grit and gravel, with sandy layers. Water......... & $220-405$ \\
\hline $\begin{array}{l}\text { Olive marl compact; some sand and grit. } \text { Lignite and fos- } \\
\text { sil plants. } \ldots \ldots\end{array}$ & $405-720$ \\
\hline Fine grit, sand, and gravel; basalt and granite pebbles..... & $720-730$ \\
\hline $\begin{array}{l}\text { Marl, "talc," shale, some gravel, and some layers of fine } \\
\text { sandstone. . . . . . . . . . }\end{array}$ & $730-850$ \\
\hline $\begin{array}{l}\text { Stiff shale and marl, some sandy layers. Many fossil plants } \\
\text { and wood } \ldots \ldots \ldots \ldots \ldots \ldots\end{array}$ & $850-1,000$ \\
\hline 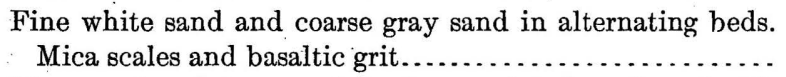 & $1,000-1,080$ \\
\hline 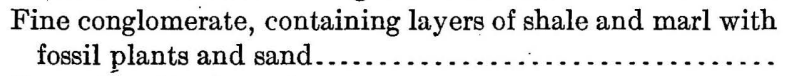 & \\
\hline Coarse basalt grit........................... & $1,200-1,250$ \\
\hline Fine-grained sandy marl and shale. Plants... & $1,250-1,300$ \\
\hline & $1,300-$ \\
\hline
\end{tabular}

Apparently in this well the older sedimentary rocks begin at a depth of 405 feet, and continue nearly 900 feet to the hard rock supposed by the drillers to be granite. The principal materials are 
shales with sandstone layers similar to the Tertiary rocks which outcrop farther west and south in the State. Unfortunately the fossil plants were neither determined nor preserved. Doubtless they would indicate the age of the strata.

In the museum in the city hall in Portland there is a fragment of sandstone containing late Tertiary fossils which, according to the label, was obtained at Sellwood or the southern portion of East Portland from the river bank during very low water. Possibly it was from a ledge underlying the basalt which crosses the river in that vicinity; on the other hand, it may have been a loose fragment brought from a distance.

Igneous rocks.-The igneous rocks in the Portland region consist of lava flows of late Tertiary age, but their history and stratigraphic relations have not been ascertained. The highlands west of Portland consist largely of basalt, which outcrops extensively in their steep eastern slope and in all of the deeper canyons. In some of the sections it may be seen that the mass is built up of successive sheets. Probably it represents a series of old lava flows lying on a surface of Tertiary sedimentary rocks not far below tide level. The location of the vent or vents and the extent of the lavas to the west have not been ascertained. The rock reaches the west bank of the Willamette at the foot of Seymour street in the southern portion of Portland, and it is exposed in the east bank in a low bluff opposite Riverside Cemetery. Thence south it is extensively exposed along the sides of the river beyond Oregon City, where the falls are over high ledges of it. Thin slices of the rock from various localities in the western portion of Portland were examined under the microscope by F. C. Calkins, who found that they were all basalts consisting of labradorite, brown augite, magnetite, apatite, and more or less glass. All but one specimen from an old quarry in Johnson Creek contain olivine also. The texture is intersertal. The feldspars are in lath-shaped crystals, with the other minerals lying between them. There are many cavities varying in size from those conspicuous to the eye down to minute irregular cavities mostly filled with secondary minerals. In the rock from Jackson Canyon just west of City Park the percentage of glass varies from 15 to 30 , and some of the rock contains roundish inclusions of finer-grained, more glassy basalt. The rock from Marquam Gulch collected on the road on the north side, well up the hill, contains 10 to 15 per cent of glass and much magnetite in grains, rods, and skeleton crystals. The basalt from an old quarry on Tanners Creek presents considerable variation, probably due to successive flows. The rock high in the slope contains only from 5 to 10 per cent of glass and much less magnetite than the other rocks. Its groundmass also contains much apatite and a few grains of olivine. The lower portion of the basalt on Tanners Creek contains 
from 25 to 35 per cent of glass and a little olivine. It is a dense black rock of great hardness.

The black "basalt" which reaches the banks of Columbia River at St. Helens is being extensively quarried, as shown in Plates IV, $A$, and V, $A$. A sample of the rock from the quarries at St. Helens was examined microscopically by A. Johannsen. While it is closely similar to the Portland basalt in composition, its structure is subophitic, so that it may be classed as an augite andesite. Its component minerals are grains of augite and feldspar laths, with some magnetite.

The prominent hill known as Rocky Butte rises out of the high terrace plain a mile northeast of Montaville, one of the easternmost suburbs of Portland. It consists of a light-colored igneous rock strikingly different in appearance from the black basalt west and south of Portland. A mass of similar rock appears in the north bank of Columbia River at Fishers Landing, where it is extensively quarried, and, judging by a small outcrop in the northern portion of the summit of Mount Tabor, it also constitutes much of the latter highland. Apparently other masses of the same rock give rise to the buttes on the same line extended southward.

Doubtless these masses indicate a line of intrusion with local bodies of lava spreading out on the surface at intervals along its course. Probably they lie on a basement of Tertiary rocks at no great distance below tide level. Rocky Butte is nearly a mile long and 400 feet high and presents a steep rocky face to the east. The rock appears to be homogeneous in character. Microscopic examination by Mr. Johannsen showed it to be basalt with diabasic texture consisting of much plagioclase with some augite and magnetite and phenocrysts of fresh olivine. The rock from quarries just above Fishers Landing was found to be a somewhat similar rock, but of fluidal texture, with frash olivine phenocrysts and grains of augite in a groundmass of dark-brown glass containing some magnetite. The basalt of Mount Tabor has porphyriticvesicular texture with phenocrysts of fresh olivine, with less augite and some magnetite. The outcrops in Mount Tabor begin just north of Belmoni street and extend in a narrow ledge northward across the Baseline road to the north slope of the hill. The high ridge south of Belmont street is so thickly covered by gravel that the structure could not be determined, but it is probable that the basalt underlies it.

Quaternary deposits.-The wide terraces on which Portland is built consist of river deposits, mainly sand, gravel, and loam in extensive sheets. These were deposited in former times by Willamette and Columbia rivers when these streams were at a higher level than now and had courses somewhat different from the present ones. Both rivers now occupy channels cut below sea level and 
are bordered by freshet plains underlain by alluvial deposits. The latter are especially wide on the south side of Columbia River above the mouth of Willamette River and on the east side northwest of Vancouver. Alluvial flats border the Willamette below Portland, notably in the lowlands of Mocks Bottom and Swan Island and about Guild Lake.

The gravels and sands of the terrace deposits show local differences in character and succession. The predominant material is a mixture of gray sand and small gravel, with scattered pebbles of larger size and occasional bowlders. Local deposits of gravel occur, while in other places the sands are nearly free from gravel. On top of the terraces there is an almost universal thin sheet of buff or reddish loam.

There is a long cross-section exposure of the terrace deposits of the peninsula in the new deep cut of the Northern Pacific Railway. This cut is over a mile long, and in its deeper portion near University Park it is about 30 feet deep. The principal material is coarse sand of gray color, rudely stratified, but with much local crossbedding. The sand contains scattered lenses and streaks of gravel and a few bowlders, some 6 inches in diameter, but most of them small. At intervals of 3 or 4 feet thin beds of clay, or mixed clay and fine sand, lie nearly horizontal. These appear dark, because they are saturated with water. At the top is a covering of fine buff loam, 4 to 6 feet thick for the greater part of the distance but thickening as it extends down the lateral slopes, especially on the north or Columbia River side of the ridge. This loam covers a large part of the peninsula except along some of the steeper slopes, where gravel or sand comes to the surface. The coarse sands appear extensively in high bluffs all along the north bank of Willamette River from St. John to Sellwood. Near St. John and in Waids Bluff the banks are 150 to 175 feet high. The sand is mostly stratified, with subordinate cross-bedding, thin clay layers, scattered pebbles, and small bowlders. East of Mocks Bottom a heavy bed of gravel and bowlders appears in the lower part of the bluff and soon presents a thickness of 30 feet. It continues for a mile, and either gives place to finer materials or sinks beneath tide level near the line of Fremont street. For the next 2 or 3 miles in East Portland the bluffs are low and mostly graded, so that no extensive exposures appear. Opposite Ross Island the bluffs are 50 to 60 feet high and present the features shown in Plates III, $A$, and IV, $B$. The predominating material is sand, but the beds in the lower half of the bluff contain a large proportion of pebbles and small bowlders.

In the eastern portion of East Portland a higher terrace which extends eastward to Rocky Butte rises from the main terrace. In the eastern part of Irvington and along the west side of Rose City 
Park steep slopes which exhibit coarse sands and gravels rise to the higher terrace. The best exposures are in several pits whose location is shown in Plate I. Much of the material is coarse and many bowlders of moderate size occur. The bedding is inclined to the southsouthwest, in part at angles as high as $15^{\circ}$. At the top is a capping 3 to 4 feet thick of buff loam, locally gravelly, lying horizontal and constituting the surface of the higher terrace. It is probable that this buff loam, which caps the entire peninsula between Columbia and Willamette rivers, was the product of a widespread submergence without strong currents after the gray sands had been laid down and the two terraces developed. It has since been eroded from portions of the slope to the south where Willamette River has cut into the bluffs.

The "heights" west of Portland are covered by a thick mass of fine-grained porous silt, ${ }^{a}$ closely resembling the loess of the Mississippi and Missouri valleys. It is several hundred feet thick in places, and lies on an irregular surface of igneous rock with a deposit of gravel intervening at one place. It constitutes the highest summits, but the igneous rocks protrude in some of the higher slopes, and they are bared in the deeper portion of the canyons and along the lower portion of the steep eastern front of the "heights." Some of the relations of this deposit are shown in figure 1. There are extensive exposures of this loess in the many new road and railroad cuts in Portland Heights, some of which exhibit from 20 to 40 feet of the material. In places it is exposed lying in the irregular and often deeply decomposed surface of the basalt. In the point of the highland just south of the mouth of Balch Canyon the loess is seen to be underlain by 40 feet or more of gravel, which lies on the basalt. This gravel, which is mostly coarse, is tightly packed in silty sand in part of pale reddish color. It is extensively exposed along the Cornell road (see Pl. V) and in new road cuts in slopes west from. Johnson street northwest. There are also excellent exposures on and near Cornell road from the line of Twenty-eighth street to Thirty-second street on the north side of Balch Canyon. At one locality it is seen extending down into a narrow canyon in the basalt now exposed in cross section by the road cutting.

The alluvial deposits are sands, gravels, loam, and silt, constituting the low flats along the rivers and also the river bottoms. Much of the material in the wide flats along the south side of the Columbia is "mud" or fine silt often containing considerable finely divided vegetable matter. There is also much fine sand, especially on the islands and along the river banks. Ross Island, which lies in the Willamette in the upper part of Portland, consists largely of gravel. In the river

$a$ This formation was discovered by J. S. Diller (Reconnaissance in northwestern Oregon: Seventeenth Ann. Rept. U. S. Geol. Survey, pt. 1, p. 485.) 
channels most of the deposits are sand or gravel, which becomes rapidly coarse grained as the stream is ascended. This is illustrated in Columbia River by the fact that fine-grained sands are dredged opposite Vancouver, coarse sands opposite Russells Landing, and gravel near Fishers Landing. In the Willamette the bed is fine sand near the bridges at Portland, but it becomes coarser above the upper bridge, and is largely gravel at Ross Island. Eight representative pebbles from the latter, examined microscopically by A. Johannsen, of the United States Geological Survey, were found to comprise quartzite, granophyre (consisting of quartz and orthoclase with granophyric texture), basalt (with olivine phenocrysts in a groundmass of plagioclase and glass), light-colored andesite and hornblende andesite (both with porphyritic plagioclase in a groundmass of feldspar), and a rhyolitic glass.

TACOMA-SEATTLE REGION.

Topography.-The surface of west-central Washington consists mostly of sand, gravel, and clay deposited by or in connection with the glaciers of the glacial epoch. In the Puget Sound region the lands are generally less than 1,000 feet above sea level and the principal type is a terrace or low ridge rising abruptly from 200 to 300 feet above tide water in inlets which ramify far inland. Low alluvial flats also exist along some portions of the sounds and along the river valleys.

Older rocks.-At the coast the surface of the older rocks lies beneath sea level, so that their outcrops are rare at most places near the sounds and inlets; farther inland, however, they are exposed at intervals. About Tacoma the nearest exposures are in the coal district near Pittsburg, Wilkeson, and Carbonado. The rocks also appear near Renton together with small masses of igneous rocks. Near Seattle Tertiary sandstones and shales are exposed in small areas. Igneous rocks also outcrop at Port Orchard.

Quaternary deposits.-While the glacial and other Quaternary deposits of the Puget Sound region vary greatly in character, glacial drift or till is the predominating material. This consists of a mixture of sand and clay in varying proportions, irregularly intermixed with bowlders and gravel, and is a product of the ice sheets which once covered the region. Three main drift sheets are recognized, the older of Admiralty till and the later Osceola till and Vashon drift. The Admiralty till appears in the lower portions of the bluffs of Puget Sound, notably along the Tacoma water front and at intervals along the east shore of Admiralty Inlet. It is a stiff blue clay usually stratified and locally filled with subangular stones and large bowlders.

Stratified drift covers a large portion of the area adjacent to the Sound region and constitutes many of the high bluffs, A large 
amount of the material is a mixture of sand and clay, or consists of these two materials interlaminated. Beds of gravel are frequently included and in places they attain a thickness of 40 to 140 feet. Many of the pebbles consist of granite, often so rotted that it falls apart on exposure to the weather. Ordinarily the gravel deposit is overlain by evenly bedded sands containing gravel in lenses and scattered pebbles. This sand member is usually about 40 feet thick; but at one locality on Vashon Island clean sands 200 feet in thicknẹss are exposed. Most of this material, however, is too fine for use in concrete.

These stratified sands and gravels are overlain by the later till, which is known as the Osceola till in the region south and east of Orting, Alba, and Eddyville, and as the Vashon drift in the areas adjoining the sound. The Vashon drift is the surface formation in a wide area about Seattle, Tacoma, Vashon Island, and the table-land lying between Admiralty Inlet and Stuck and White rivers. It is composed of sand and gravel with pebbles mostly rounded and consisting largely of granite and other crystalline rocks. More or less clay and silt are intermixed in portions of the deposit. There are many localities, however, at which the material can be worked to advantage and by washing and screening sorted into gravel of various sizes, coarse sand for concrete, and fine sand for mortar. This process has been effected in a measure by nature in places where the original drift has been modified extensively by running streams of the glacial epoch.

The local variations in the character of the material are so great that it is not possible to describe the distribution of the various materials. One of the most extensive and notable members, which has been called Steilacoom gravel, occupies the greater part of the summit of the extensive plateau south of Tacoma, extending from the bank of the Puyallup Valley westward to the shore of the Sound southwest of Tacoma. Lake Spanaway lies on this surface and the formation appears in high banks at Steilacoom. The gravel is mostly coarse, hard material, and washed clean of fine sand and clay, although on the surface there is frequently a thin layer of sandy loam. Considerable coarse sand or fine gravel is intermixed, together with many bowlders, mostly of small size. This deposit is the product of a river which flowed westward at an early portion of the glacial epoch.

\section{STRUCTŨRAL MATERIALS.}

GRAVEL AND SAND.

- Portland region.--Very nearly all of the large amount of gravel used for concrete construction in Portland is obtained by dredging from the Willamette River channel in or just above the city. The material is pumped up by dredges, screened and washed in the elevators, and 


\section{STRUCTURAL MATERIALS IN OREGON AND WASHINGTON.}

loaded directly onto scows. (See Pl. II.) The process is so cheap that the gravel is sold for about 80 cents a cubic yard at bins located at several points along the water front in Portland. Several dredges are in operation most of the time. At high water the gravelly shores of Ross Island, then inundated, are dredged. The gravel consists largely of volcanic rocks, basalt and andesite (see p. 12), together with quartz and quartzite. The pebbles average in large part from one-half to $1 \frac{1}{2}$ inches in diameter, but they vary greatly in different portions of the dredging grounds. The amount of material available is large, for the gravel banks extend for several miles up and down stream and vary from a few rods to a half mile in width. Their depth is unknown, but is probably great. Every freshet adds to the supply. A small amount of gravel is at times obtained from Columbia River near Fishers Landing, but the material includes a large proportion of scoriaceous or spongy rock called "honeycomb," which is much less tough than the gravel of Willamette River. It is, however, in large deposits and is obtainable at low cost.

- Very extensive beds of gravel underlie parts of the uplands in the Portland and Vancouver regions, and while they are dug for road making, they have not been utilized extensively for concrete. They are considerably more expensive than the river gravels, except for use at points far from tide water, when the item of hauling becomes a large factor in the expense. One of the largest exposures of these deposits is on the east bank of Willamette River opposite Ross Island. The river banks at this place are from 55 to 65 feet high, and although much of the deposit is sand, portions of it consist mainly of gravel. One bed of gravel about one-third way up the bluff extends for nearly a mile, with a thickness of 12 to 15 feet. A large amount of material has been removed from the bluff for grading an electric line that has been built along the river. Plates III, $A$, and IV, $B$, present two views of the deposit, one of them showing a steam shovel in operation. This bank extends eastward under the south part of East Portland, and its top is laid out in city lots, probably of too great prospective value to permit very extensive invasion by quarrying operations. A similar bluff of gravel and sand also extends north along the northeast bank of the river below Portland to St. Johns, and while the predominating material is sand, much gravel could be screened out of it. Opposite the south end of Swan Island the bluff contains a 30 -foot bed of gravel and bowlders, which extends to the built-up district adjoining the yards of the Oregon Railroad and Navigation Company. Its thickness and purity diminish materially to the southeast. The steep terrace slope extending through East Portland from the west end of Rose City Park along the northern portion of Irvington consists of a thick deposit of gràvel, which is worked for road material at several large pits. The amount 


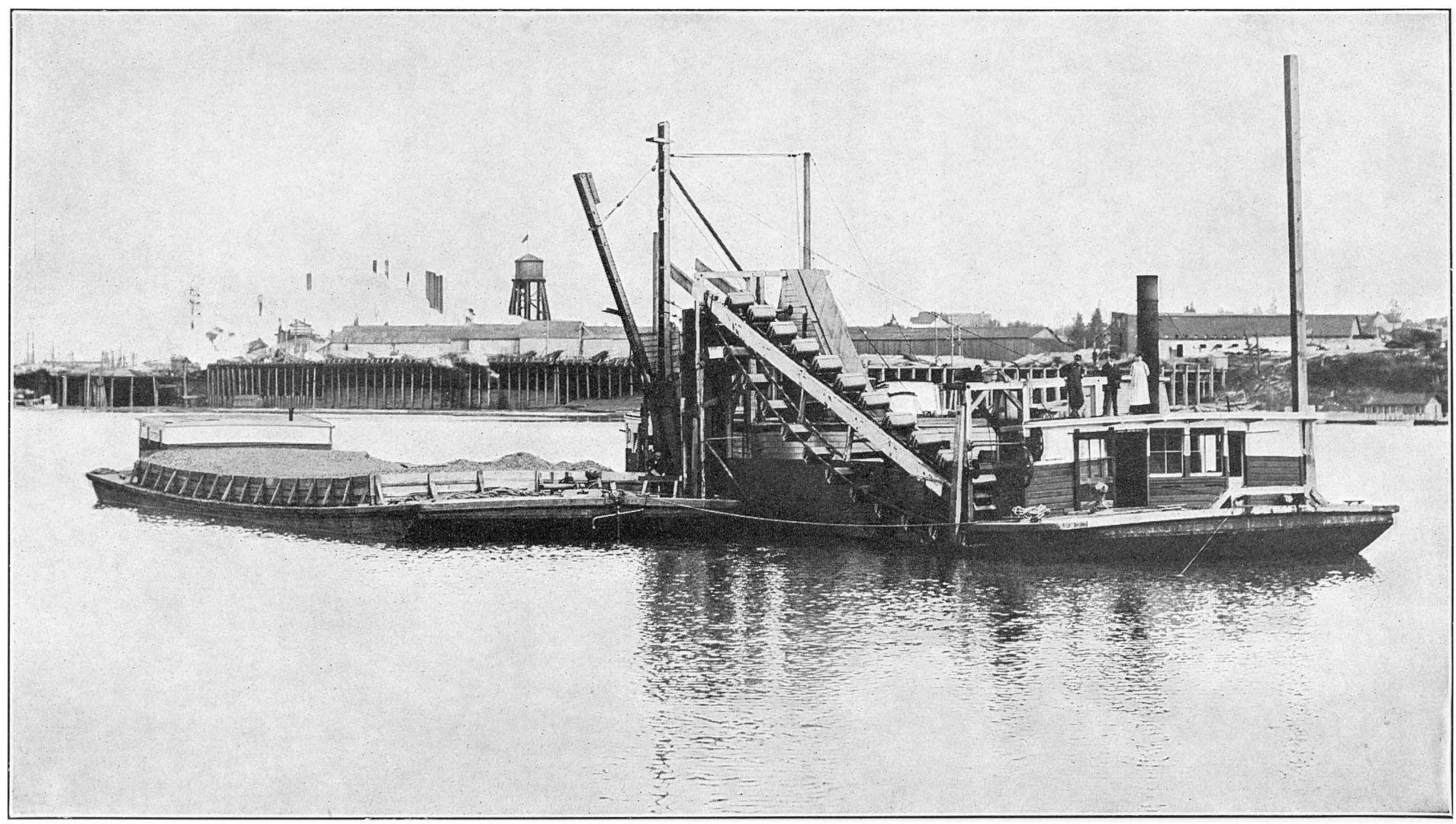

DREDGE USED FOR RAISING CONCRETE GRAVEL FROM BED OF WILLAMETTE RIVER AT PORTLAND, OREG. 


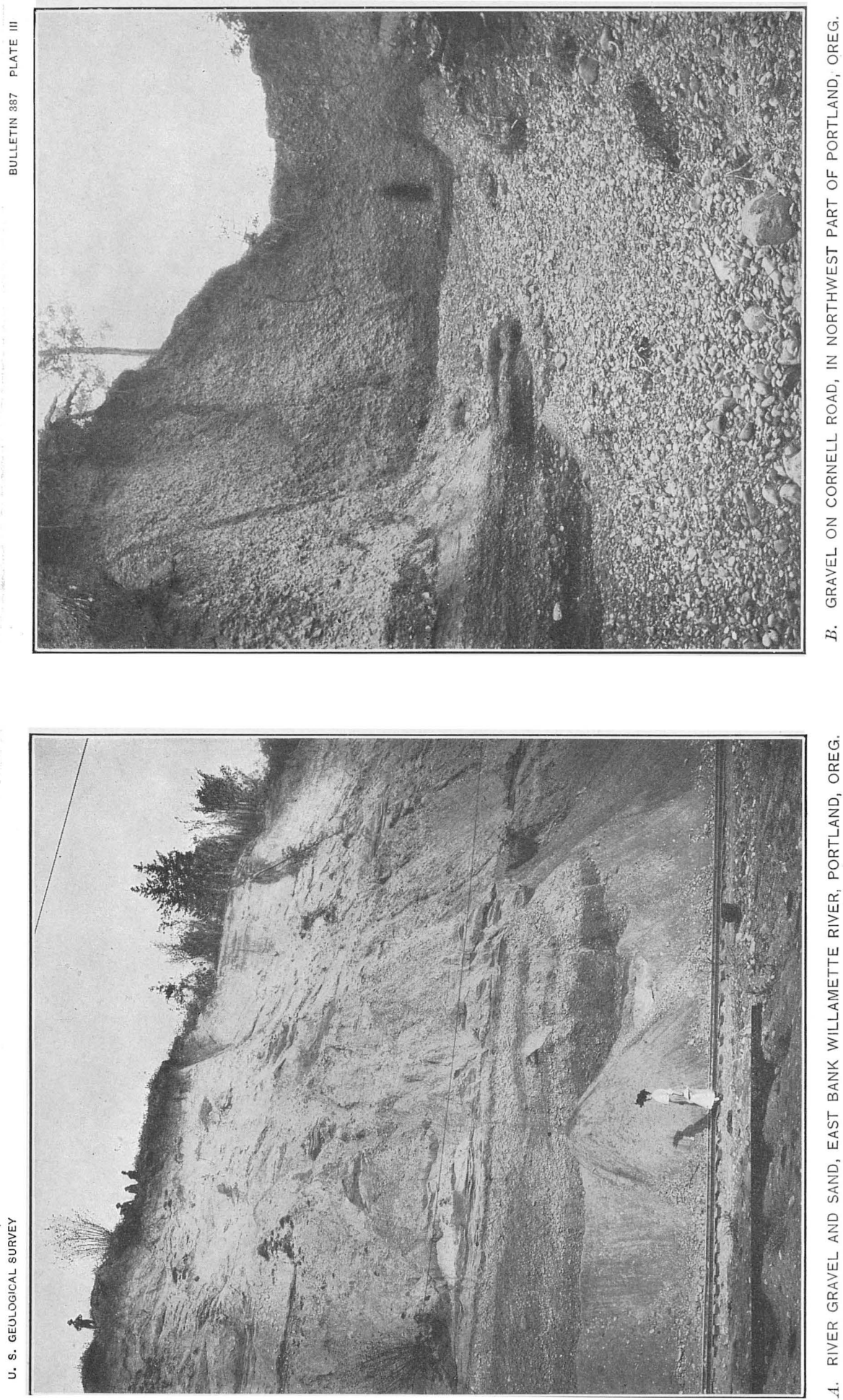

of gravel available in this area is very large, but with the increasing value of the land for building lots it is improbable that the workings will become extensive. Some thick deposits of gravel lie against the slope of the high ridges just south of the mouth of Balch Canyon, and they have been worked to a small extent for road making. One of the exposed faces near Cornell road is 40 feet high, and other smaller ones are exhibited in cuts for new roads. Some features of these gravels are shown in Plate III, $B$.

Seattle-Tacoma region.-A large proportion of the gravel and sand used for concrete in Tacoma and Seattle is obtained from extensive quarries on the high banks of the Sound a short distance north of Steilacoom, where a thick wide sheet of Steilacoom gravel lying on the till probably represents the course of a powerful stream during glacial time. The deposit is worked by several companies who excavate the material by hydraulic jet and wash and screen it down grade into storage bins, whence it is loaded onto barges and towed to Tacoma and Seattle. A view of one of the works is given in Plate VIII, $B$. The total production is about 1,000 yards a day. Representative samples of concrete sand and gravel from this locality were sent to the St. Louis laboratory of the United States Geological Survey for a working test.

Gravel and sand for concrete and other uses are obtained extensively from Richmond Beach, a station on the Great Northern Railway on the shore of Puget Sound about 12 miles north of Seattle. The deposit is about 150 feet thick in the center, where it constitutes nearly the entire bluff, but the thickness diminishes gradually to the north and south. It lies on glacial till and appears to represent a river channel of the glacial epoch. The material is worked by a hydraulic jet supplied by water obtained from springs on the tableland just east. It is washed over screens into large storage bins, and is loaded from these directly onto cars or barges. The capacity of the plant is about 500 yards a day. Representative samples of coarse sand and gravel for concrete were obtained at this place and sent to St. Louis to be given a series of working tests:

Gravel and sand are obtained from pits at Eagle Harbor on the opposite side of Puget Sound from Seattle and on the west side of Vashon Island near its north end. The workings are in the high banks rising steeply out of the sound and the material is loaded directly onto barges. The washing is done by sea water pumped to tanks on top of the bank. The capacity of the Vashon Island works is 300 yards a day. A large proportion of the material is fine sand, used for plastering.

Gravel and sand for concrete are sold at an average price of about 90 cents a yard in Seattle and Tacoma, not including cost of hauling from the bins. 
Gravel and sand are dug in moderate amount at several localities in the city of Tacoma and while sand for mortar or plastering is the principal product, considerable coarse sand and gravel for concrete are obtained. The largest and best equipped plant is at Thirty-first and East $\mathrm{E}$ street; it is shown in Plate V, $A$. It uses city water for hydraulicking the material from a high bank into a sluiceway, whence it is elevated to screens, washers, and bins, and thoroughly cleaned and sorted.

In Seattle there are many small plants for producing sand and gravel from the extensive deposits which occur in the glacial till and modified drift in most parts of the city and vicinity. Some of these plants, such as are shown in Plates V, $B$, and VI, are temporary ones operated to reduce hilly slopes to the city grade and convert them into building lots, meanwhile utilizing the products as building materials. The proportion of gravel and coarse sand varies from place to place, the coarser deposits giving place to clays and finer sands. Some of the latter are extensively utilized for mortar and plastering, and in fact the principal supplies of these materials are obtained locally, often from the excavation for the foundation of the building in which they are used. There are gravel pits of moderate size, with plants for washing, screening, etc., on the east bank of Lake Union and at the north end of Green Lake. Plans have been developed for large pits at the east end of Lake Washington and near Brighton Beach.

\section{BROKEN ROCK.}

Portland region:-Broken rock is used only to a very small extent for concrete in Portland. This is due largely to the fact that the production from several quarries is scarcely sufficient to supply the demand for macadam and other road material and the price is considerably higher than that of gravel. Eventually, when the quarries are more extensively developed, this material also may be used, especially if it be found stronger than gravel.

The largest part of the broken rock brought to Portland is quarried on the bank of Columbia River, a short distance below St. Helens. This locality is about 30 miles northwest of Portland, but direct tidewater connection makes the expense of transportation very low. The quarries are in the bluff about 100 feet above the river, and all of the products are loaded on large scows by gravity. (See Pl. VII, A.) The rock is a fine-grained augite andesite of nearly black color, which outcrops in prominent ledges, usually presenting well-marked columnảr structure. It occupies an area of about 2 square miles, extending westward to the railroad. The amount of material available is very large. One of the principal products of the quarry is paving blocks. The large amount of waste which results is crushed, screened, and 


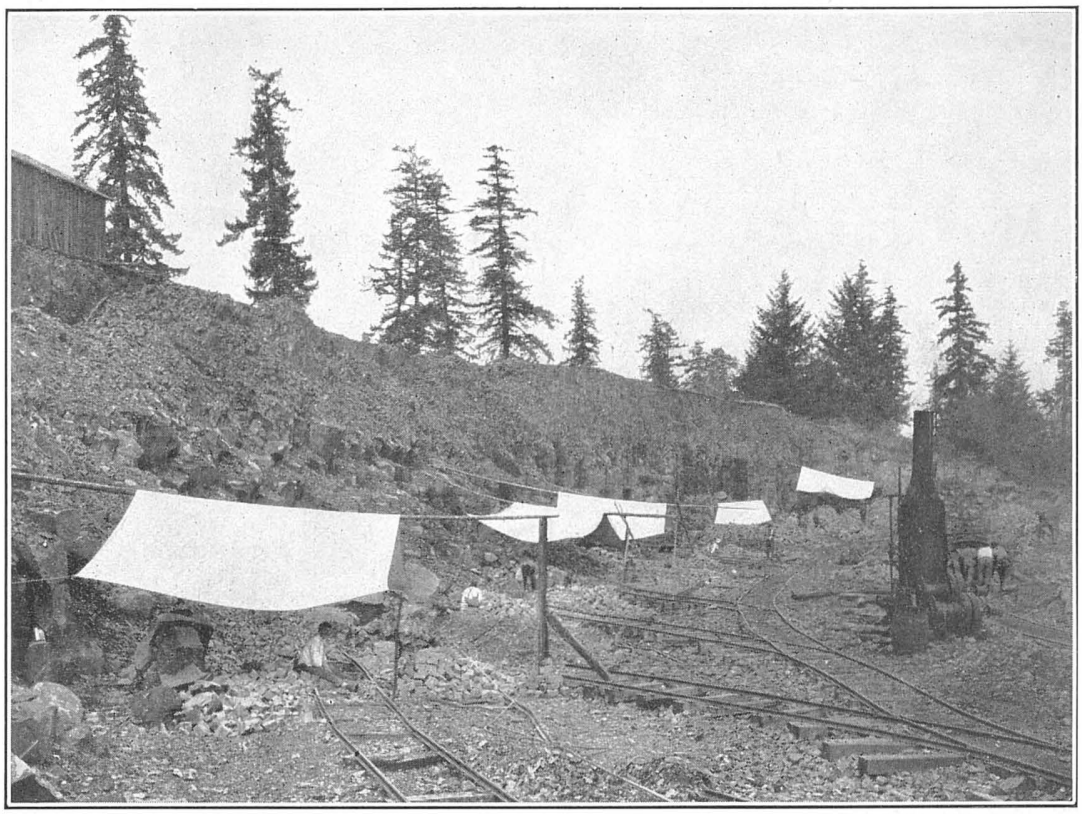

A. LOWER QUARRY NEAR ST. HELENS, OREG.

In Anoesite used for paving blocks and crushed rock.

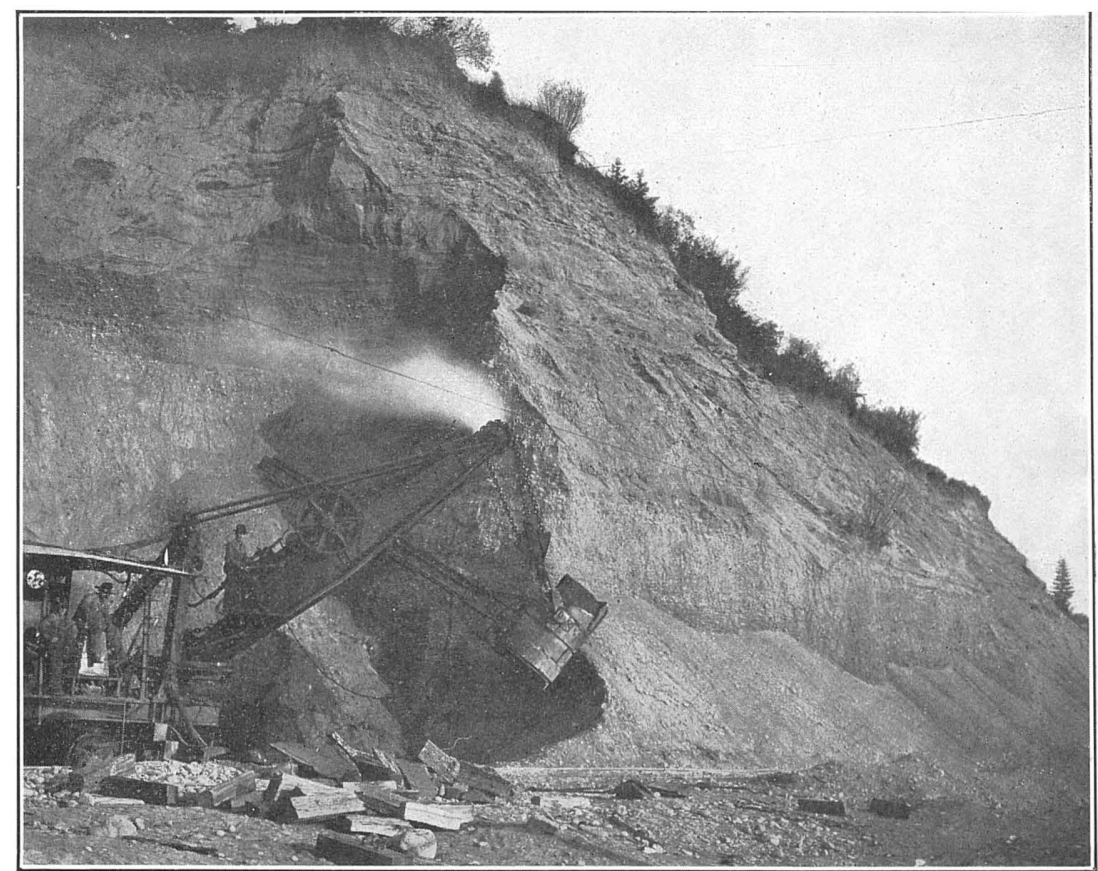

B. GRAVEL AND SAND ON EAST BANK OF WILLAMETTE RIVER, PORTLAND, OREG. 



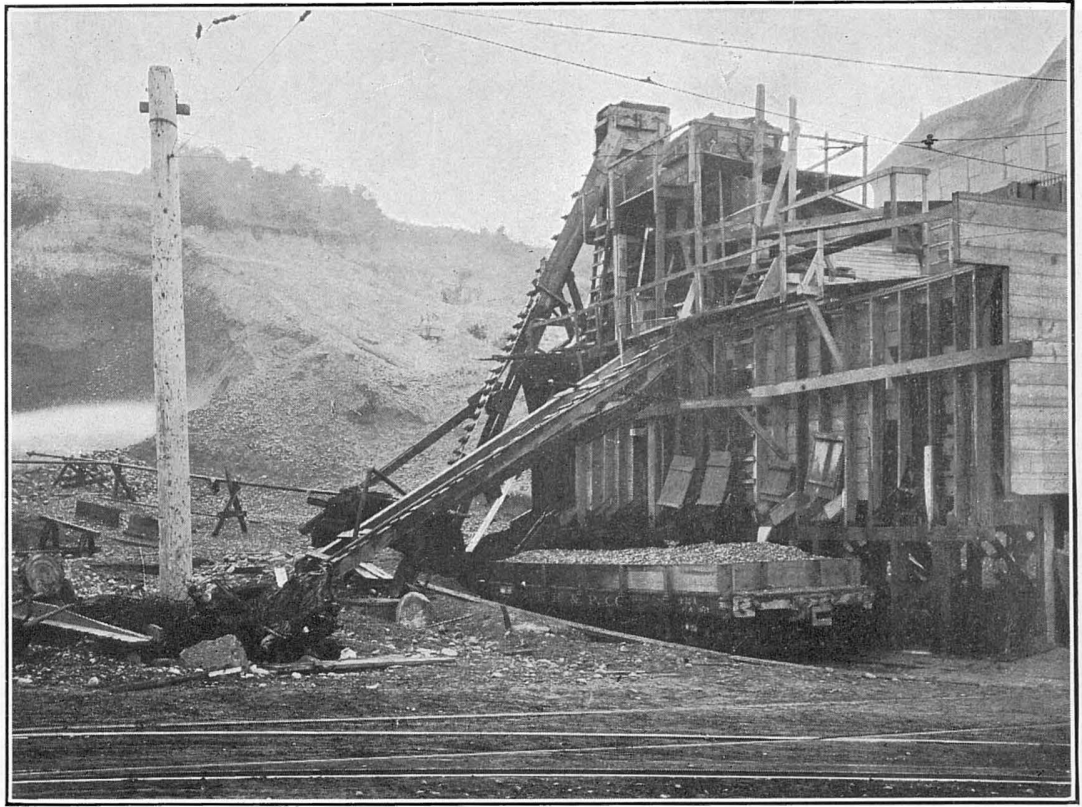

A. GRAVEL PIT IN SOUTHERN PART OF TACOMA, WASH.

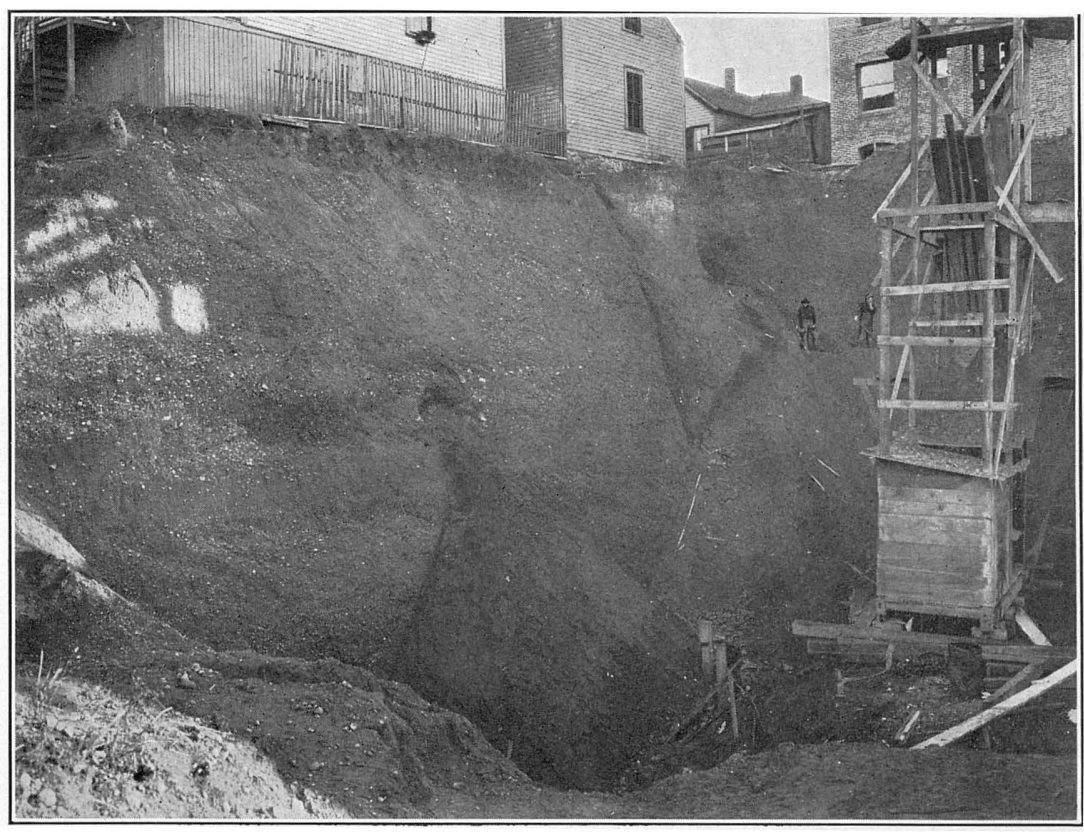

B. Gravel pit on bellevue avenue, near pike street, Seattle, wash. 

shipped as crushed rock for road material. More than 2 tons of this rock were sent to St. Louis, for working tests in concrete to be made later. 'The rock is free from honeycomb structure, very dense, and exceedingly hard, but somewhat brittle. Notwithstanding this latter quality, working tests demonstrate that it possesses great toughness when used as a component of concrete. It is sold for $\$ 1.50$ a yard on the dock at Portland.

In the vicinity of Portland a large supply of rock is available from the dark-colored basalt constituting the eore of the highlands immediately west of the city and the river banks above the city, notably at the falls of the Willamette at Oregon City. The rock outcrops extensively in the canyons in the western portion of Portland, and at various localities in some of these it has been quarried and crushed. The product has been employed almost exclusively for road material, with very satisfactory results. Portions of the rock, however, are scoriaceous or honeycombed, which greatly diminishes its strength. Some of the quarries have been abandoned because of this feature, for although much of the rock was solid, there was a very large amount of waste of the scoriaceous part. The two principal quarries now in operation are in Marquam Gulch. There are also quarries on the river bank near Oswego, a few miles above Portland.

The basalt of Rocky Butte, a short distance east of Portland, is a hard, coarse-grained gray rock of considerable toughness. Several small quarries have been opened on its steep eastern face for building stone for local use, and at one time a spur was built along its northeast face by the Oregon Railroad and Navigation Company. The length of the ridge is very nearly 1 mile, its width is considerably over 1,500 feet, and its height above the adjoining lands is 300 to 400 feet. These dimensions indicate a volume of about $83,000,000$. cubic yards of the rock, or over 200 million tons within easy reach for excavation. The rock appears to be uniform in texture, freefrom honeycomb, and the joints by which it is traversed are so far apart that large blocks are easily obtainable. It dresses readily and is of a light-gray tint of very much more pleasing appearance than the black basalt, which has been used to some extent for building in Portland. Although the basalt outcrop in Mount Tabor is very small, doubtless the rock is much more extensive underground and may be found to constitute a large part of the nucleus of the Mount Tabor highland. It is massive, homogeneous in texture, of lightgray color, and of considerable toughness. Most of the outcrop ledges show very large blocks, which appear to have been very little affected by weathering. A deposit of coarse bowlders on Mount Tabor, which could be crushed for broken rock, consists largely of hard volcanic rocks, but includes considerable quartz and quartzite. 80594-Bull. 387-09-2 
Some of the best exposures of the material are in the slopes adjoining the reservoir in the south end of the ridge.

The basalt which rises in high bluffs on the north side of Fishers Landing is extensively worked in a series of large quarries. The material is taken out in large blocks for use on the jetties at the mouth of Columbia River and Grays Harbor. One of these quarries is shown in Plate VII, $B$.

Seattle-Tacoma region.-Crushed rock is produced in considerable amount from two localities in the Seattle region. It is not used for concrete, however, owing to its cost, which is $\$ 1.40$ per yard, nearly twice that of gravel. One large quarry is a mile above Charleston or Port Orchard, at the head of the inlet, and another is on the suburban trolley line, 2 miles south of South Park, between Seattle and Renton. The rock is a dark-colored andesite of igneous origin, very hard and dense, but somewhat brittle. At the quarry south of Seattle the rock rises in cliffs about 100 feet high on the west bank of Duwamish River. The material is used entirely for admixture with asphalt in paving.

CLAY.

Portland region.-Clays of various kinds occur in the Portland region, and they are utilized to a moderate extent. Brick is the principal product, and in fact the clays of the immediate vicinity of Portland appear not to be useful for anything else. Within a radius of 100 miles, however, clays suitable for terra cotta and other building materials are found, but as yet no special attention has been given to them. Brick loams occupy the surface at many places in the wide terrace areas about Portland, and they are burned into brick at several localities. The pits and kilns are mostly in East Portland, in areas where the land is not too highly valued for building lots. Brick works of moderate size at Sylvan and in Johnson Gulch west of Portland use a sandy clay from the base of the loess. Many bricks for use in Portland are made at Russells Landing, on the north bank of Columbia River, 5 miles above Vancouver, where 20 feet of gray brick loam overlies 6 feet thick of purer blue clay; part of the pit is shown in Plate VIII, $A$. The blue clay has been mixed with shale brought from coal mines in Washington and used for making terra cotta.

Seattle-Tacoma region.-Clay forms a considerable proportion of the glacial and other Quaternary deposits in the Seattle-Tacoma region, and it also occurs in the form of. soft shale in the coal measures at Renton, Taylor, Kummer, etc. The clay near the two cities is used extensively for making common red brick to supply the local demand. Terra cotta and other building materials are made from the purer clays of the coal measures, especially at the points above mentioned. 


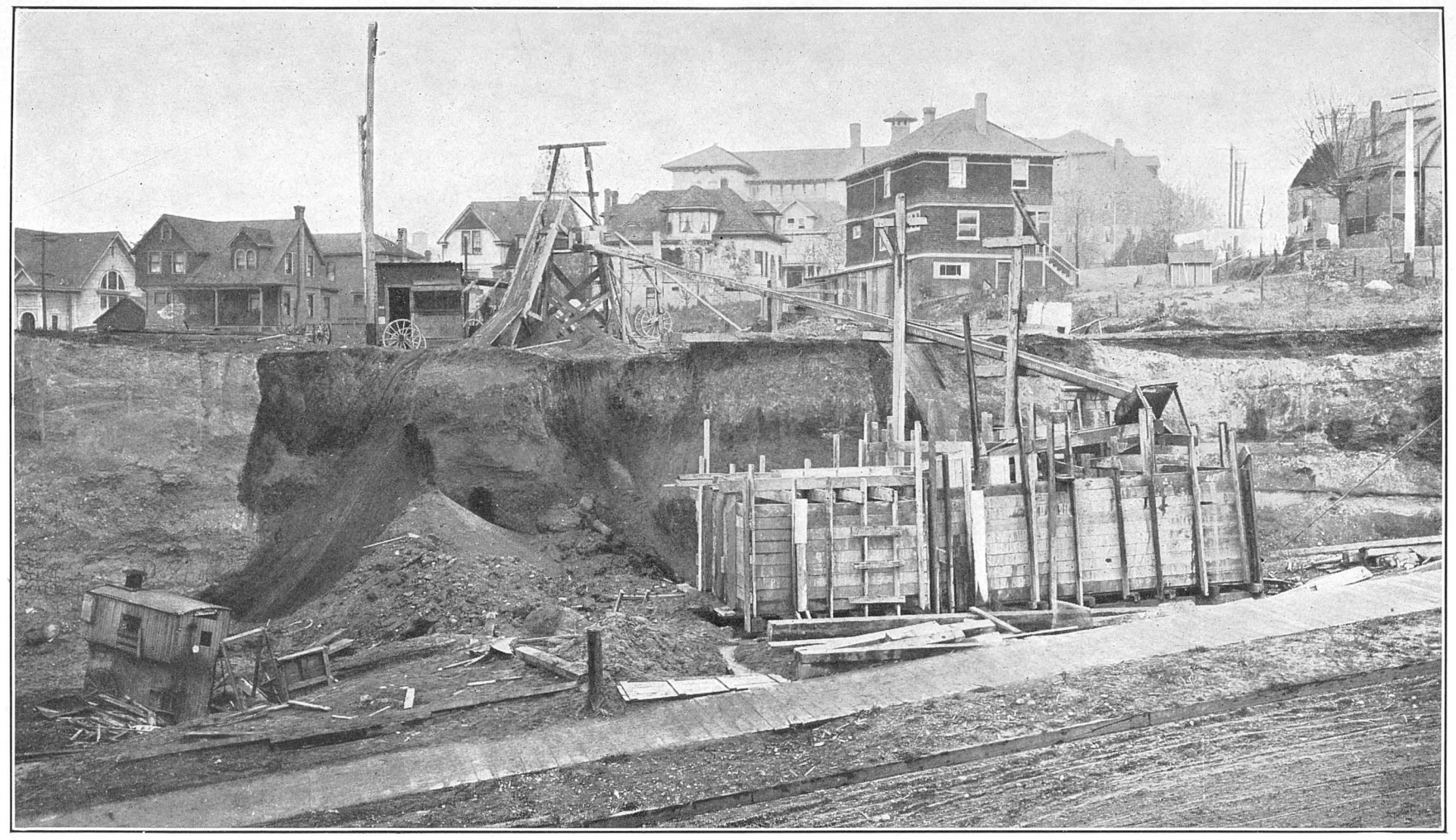

TEMPORARY GRAVEL AND SAND PIT, WITH SCREEN, WASHER, AND BIN, BOREN AVENUE, NEAR PIKE STREET, SEATTLE, WASH. 

No special study was made of the clays in the Seattle-Tacoma region, so that the extent and character of the deposits and the relative merits of the products can not be given.

BUILDING STONE.

Oregon.-While a large amount of building stone is used in Portland, an exceedingly small proportion of it is obtained in the vicinity of the city. The basalt and andesite of the region have furnished material for a few buildings, but this was mostly in years past, supplies nowadays being shipped by rail and in small part by water from neighboring States. One of the materials most extensively used is the dark greenish-gray sandstone from Tenino, Wash., but various other sandstones, granite, and limestones are employed. Most of the granite has been brought from long distances. The custom-house in Portland is built mostly of granite from the quarries in Snake River, 30 miles below Lewiston, Wash.

The black basalt constituting the greater portion of the highland west of Portland has been utilized for a few buildings in Portland and for many walls and foundations. It is of great hardness and toughness, especially when rock free from "honeycomb" is selected, and it can be obtained at moderate cost, especially as a partial product from quarries worked mainly for road metal. Its dark color and the difficulty in dressing it appear to be the principal objections to its use. The gray basalt of Rocky Butte has been used to some extent in foundation work and to a small extent in building. Lately the demand for it has increased and some small quarries are being opened in the east side of the butte. The rock has a pleasing gray color, is not difficult to dress, and is of great durability. Much of it can be easily worked out in large blocks.

Washington.-Practically all of the building stone used in Seattle and Tacoma is brought from distant points, some of which are, however, in the State of Washington. Large bowlders in the glacial till afford material for walls and foundations, and a few private houses have been built of them. The only "ledge rocks" occurring near the cities are the andesite, 2 miles south of South Seattle, and some beds of sandstone in the lower part of South Seattle. These have been used to a very small extent for foundations and do not offer any promise of being utilized extensively as building stones.

PLASTER.

Plaster of Paris and various "stucco" preparations are shipped from various places to the cities on the northwest coast. These products are prepared from gypsum, a mineral which has not been found 
in any quantity in Washington, but which occurs in large deposits near Huntington in eastern Oregon. These deposits are worked extensively, and much of the product goes to Portland, Seattle, and Tacoma. They have been known for many years, but worked only during the past decade. The plant is on Burnt River, 3 miles northwest of Huntington, and the deposits are in the ridge that separates the valleys of Burnt and Snake rivers. According to Lindgren, ${ }^{a}$ the principal bed of gypsum is 20 feet thick and of excellent quality. Much of it is pure white and crystalline, but parts contain thin films of greenish chloritic material. It rests on slate and limestone and is covered by red and green tuffaceous slate in a series dipping gently to the west. About 80 feet higher up is another gypsum stratum, 30 to 40 feet thick, covered by gypsiferous limestone and green volcanic tuff. The gypsum deposits are in elongated lenses. They are worked by tunnels, entering about 200 feet below the summit of the ridge on the Snake River side. The production is stated to be about 13,000 tons a year.

\section{PORTLAND CEMENT.}

A very large amount of Portland cement is used in Oregon and Washington for concrete construction, especially in the larger citiesPortland, Seattle, Tacoma, etc. Much of the material is imported from Germany, Belgium, England, and Japan, and a small amount is brought by water from California. Its cost reached $\$ 3.75$ a barrel during 1907, but averaged $\$ 3$. It is estimated that the total amount of cement used in the three cities above mentioned in 1907 was $1,294,800$ barrels; with a value of about $\$ 3,884,400$. Of this amount 381,356 barrels were imported into Portland and 369,516 barrels into Puget Sound ports. The latter region also received 263,458 barrels from domestic sources, about two-thirds from California. Several companies have recently been projected for producing cement at various localities in Oregon and Washington, but the only plant now existing is that of the Washington Cement Company at Concrete, a station on a branch of the Great Northern Railway in central Skagit County. The plant was built in 1905 and started in 1907. It has two 100-foot rotary kilns, but will soon add others to the full capacity of the water power, which is derived from Baker River, on the bank of which the works are erected. A 6 by 10 foot flume carries the water about $2 \frac{1}{2}$ miles to the works. Crude oil is used for the kilns and driers. A large supply of high-class limestone is obtained from quarries near by and clay is excavated from the river banks.

The following analysis of the cement was furnished by the company: 


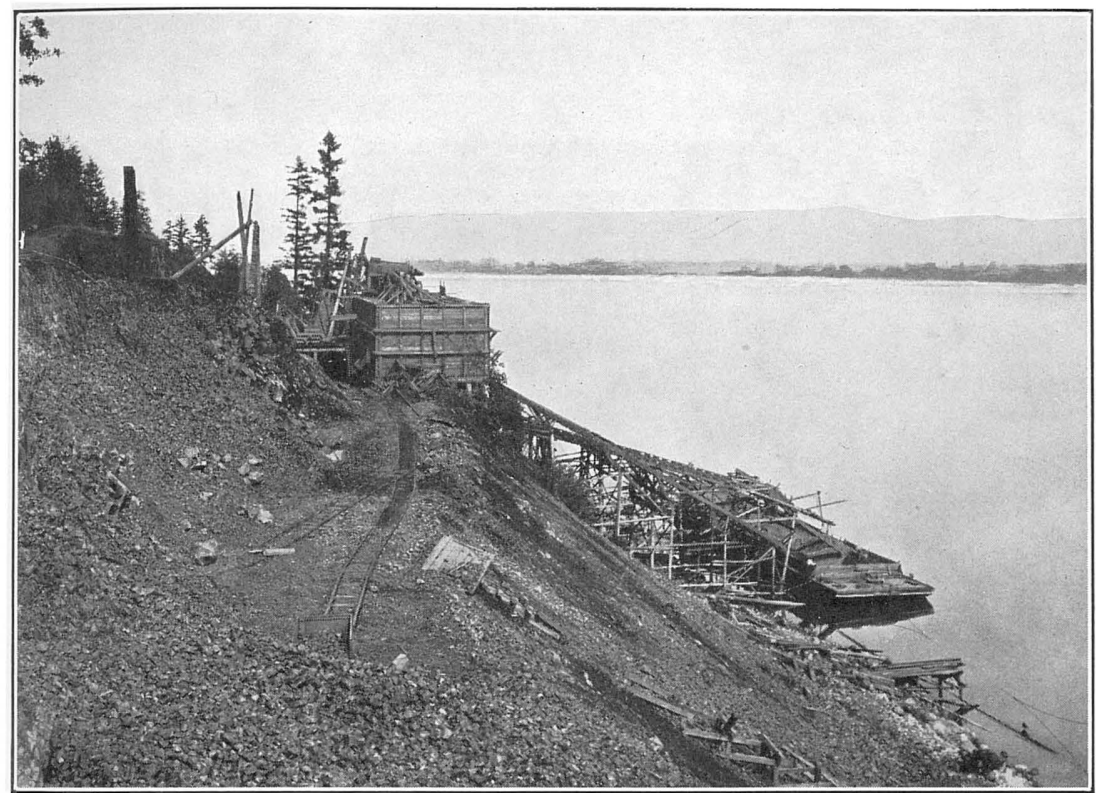

A. UPPER QUARRY, CRUSHER, AND LOADING INCLINE, SOUTH BANK OF COLUMBIA RIVER, NEAR ST. HELENS, OREG.

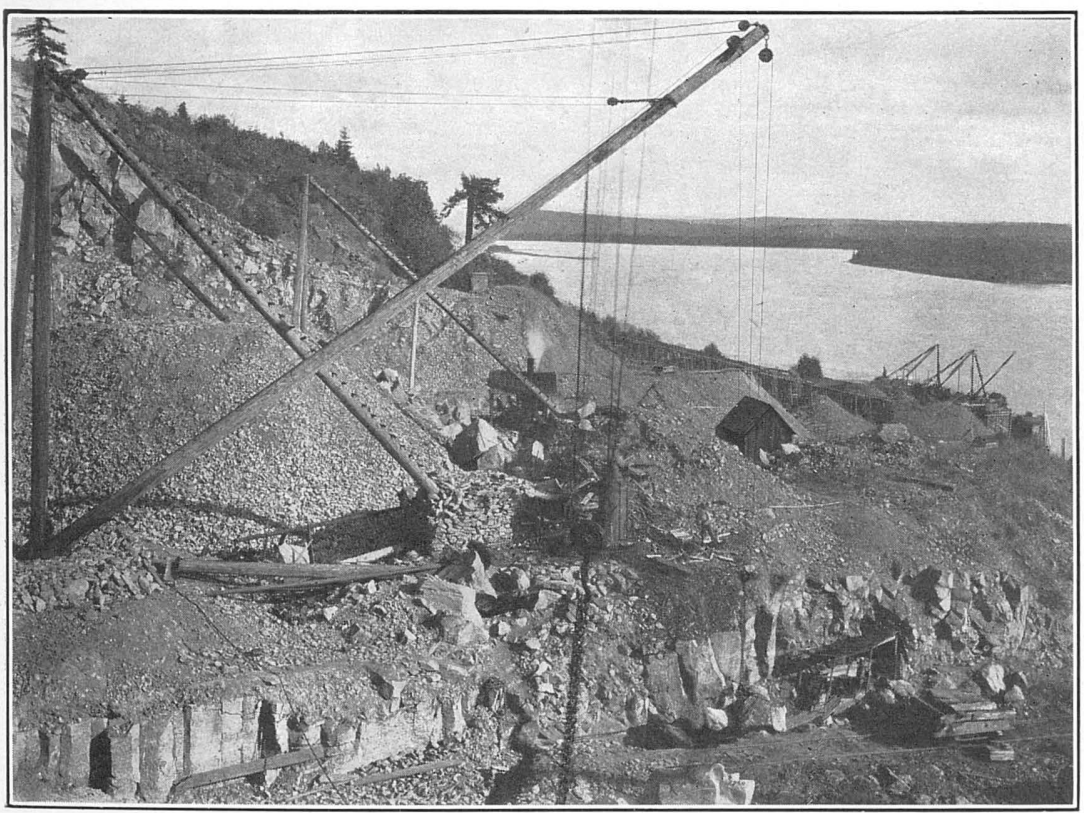

B. QUARRY NEAR FISHERS LANDING, COLUMBIA RIVER, WASHINGTON.

Shows loading incline. 

Analysis of Portland cement from Concrete, Wash.

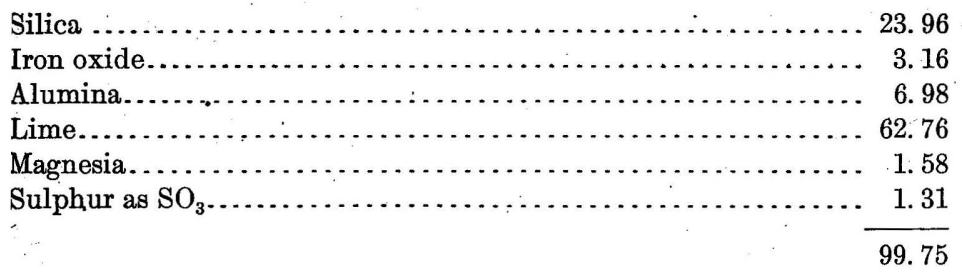

Ninety-nine per cent of the cement will pass through a 100-mesh screen and 83 per cent through a $200-$ mesh screen. The setting time is given at $4 \frac{1}{2}$ hours for initial set and 8 hours for final set. The tensile strength is given as follows: Twenty-four hours, neat cement, 295 pounds; seven days, neat cement, 773 pounds; seven days, 1 to 3 sand, 276 pounds; twenty-eight days, neat cement, 805 pounds; and twenty-eight days, 1 to 3 sand, 440 pounds. The boiling test gave perfect results. This cement has been extensively tested and several contractors in Seattle assert that it comes up to the best requirements.

From 1887 to 1890 a cement plant was operated at Oregon City by the Portland Cement Company, of Portland, Oreg. This plant was the first to use rotary kilns. A "natural cement rock" from Douglas County, Oreg., was burnt, using gas for fuel, and power from Willamette River. Owing to litigation it was shut down in 1890. Undoubtedly the great expense of hauling limestone from Douglas County was a serious handicap to the project.

\section{CEMENT MATERIALS IN WASHINGTON.}

Limestone suitable for cement is known to occur at various localities in the State of Washington, but only the deposit in Skagit County is utilized for cement manufacture. Many of the limestone bodies occur far off the main lines of travel and some of them are not sufciently pure for cement. Doubtless when the geology of the State is completely explored numerous additional localities will be discovered. Many of the following descriptions of known occurrences are condensed from a report by Prof. Henry Landes. ${ }^{a}$

San Juan County.-The principal deposits of limestone in San Juan County are on San Juan and Orcas islands at or near tide-water level. On San Juan Island the rock has been extensively worked and burned into lime at Roche Harbor, furnishing the principal supplies for the northwest coast. The rock is a marble included in a series of metamorphic rocks of pre-Cretaceous age. It appears in two large ledges which extend north and south from Roche Harbor to Westcott Bay, a distance of about one-half mile. The width of outcrop from east to west is about 1,000 feet and the ledges rise 200 feet in the slopes. The rock is considerably shattered and mostly bare, so that it is easily 
quarried. The quarry, which has been in operation since 1882, produces about 300,000 barrels of lime a year. The limestone is very uniform in character and composition, as shown by the following analyses:

Analyses of limestone from Roche Harbor, Washington.

\begin{tabular}{|c|c|c|c|c|}
\hline 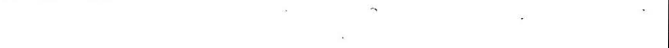 & 1. & 2. & 3. & 4. \\
\hline 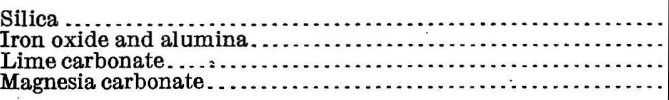 & $\begin{array}{r}0.44 \\
1.13 \\
98.21 \\
9\end{array}$ & $\begin{array}{r}0.27 \\
0.21 \\
99.06 \\
.46\end{array}$ & $\begin{array}{r}0.20 \\
0.30 \\
98.57 \\
1.02\end{array}$ & $\begin{array}{r}0.14 \\
0.10 \\
98.75 \\
.42\end{array}$ \\
\hline & 99.78 & 100.00 & 100.09 & 99.41 \\
\hline
\end{tabular}

1. Made in 1888 by Moss Bay Hematite and Iron Company, England.

2. Made in 1893 by Puget Sound Reduction Company, Everett, Wash.

3 . Made in 1902 by C. F. McKenna, New York, N. Y.

4. Made in 1906 by Spackman Engineering Company, Philadelphia, Pa.

The limestone of Orcas Island outcrops at several points on the northwest shore of the island near East Sound and Deer Harbor, and while the rock is a marble similar to that at Roche Harbor its area is less. It has been burned to lime to a small extent and yielded a most satisfactory product. Two analyses of the rock by A. H. Cederberg are as follows:

Analyses of limestone from Orcas Island, Washington.

\begin{tabular}{|c|c|c|}
\hline . & Sample 1. & Sample 2. \\
\hline \multirow{4}{*}{ 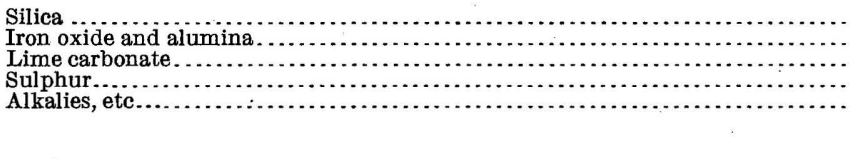 } & $\begin{array}{r}1.61 \\
.04\end{array}$ & $\begin{array}{c}1.14 \\
.\end{array}$ \\
\hline & 97.45 & 97.23 \\
\hline & $\begin{array}{r}\text { Trace. } \\
.51\end{array}$ & $\begin{array}{r}\text { Trace } \\
1.21\end{array}$ \\
\hline & 99.61 & 99.89 \\
\hline
\end{tabular}

Extensive deposits of clay in the glacial deposits and of shales about Roche Harbor and Orcas Island could be used with the limestone for cement manufacture. The topographic conditions also are favorable, especially in the presence of water so deep that large vessels can come close to the shore. Analyses of clays and shales are as follows:

Analyses of clays and shales from Roche Harbor and Orcas Island, Washington.

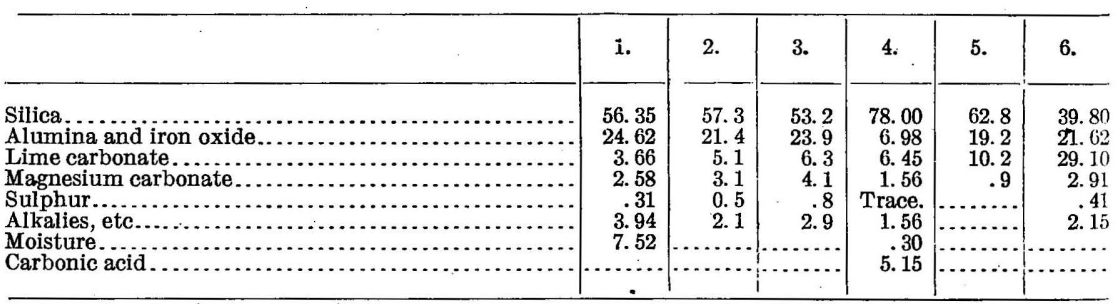

1. Clay from Roche Harbor; F. C. Newton, Seattle, Wash.. analyst. 2 and 3 . Clays from Orcas Island; A. H. Cederberg, analyst:

4. Slate from Roche Harbor; F. C. Newton, Seattle, Wash., analyst.

5 and 6 . Shale from Orcas Island; A. H. Cederberg, analyst. 


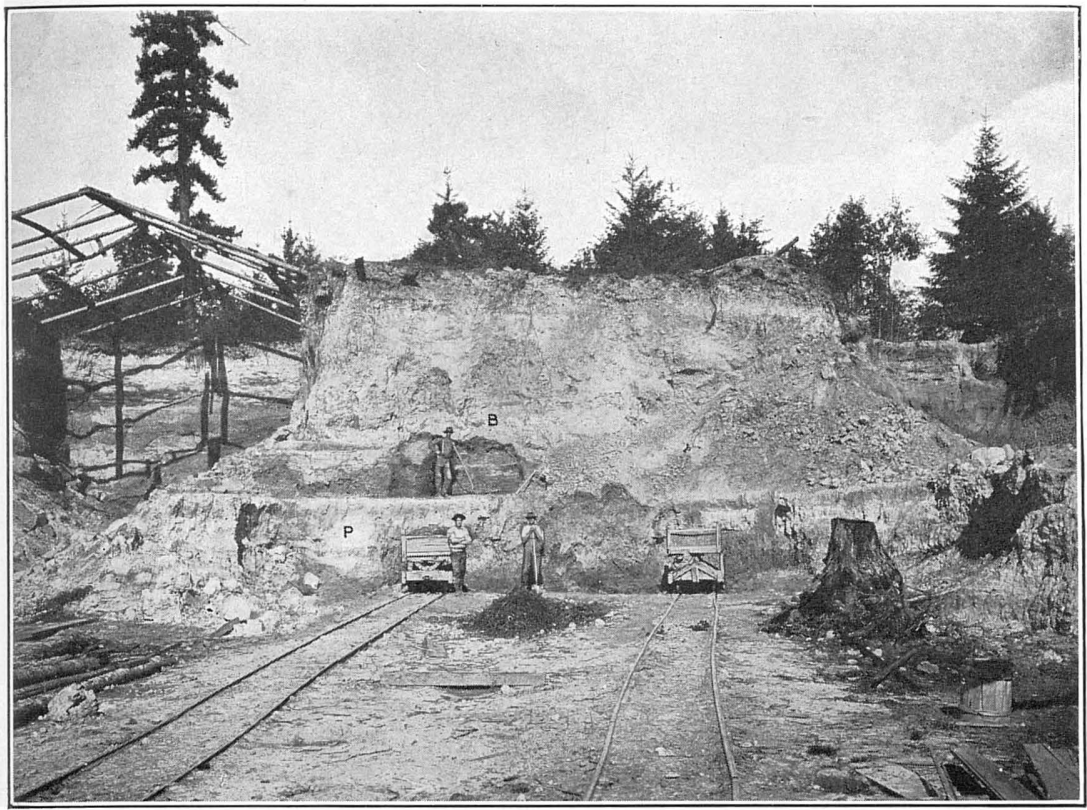

A. CLAY PIT AT RUSSELL LANDING, 4 MILES ABOVE VANCOUVER, WASH.

P, Terra-cotta slay: B, brick loam.

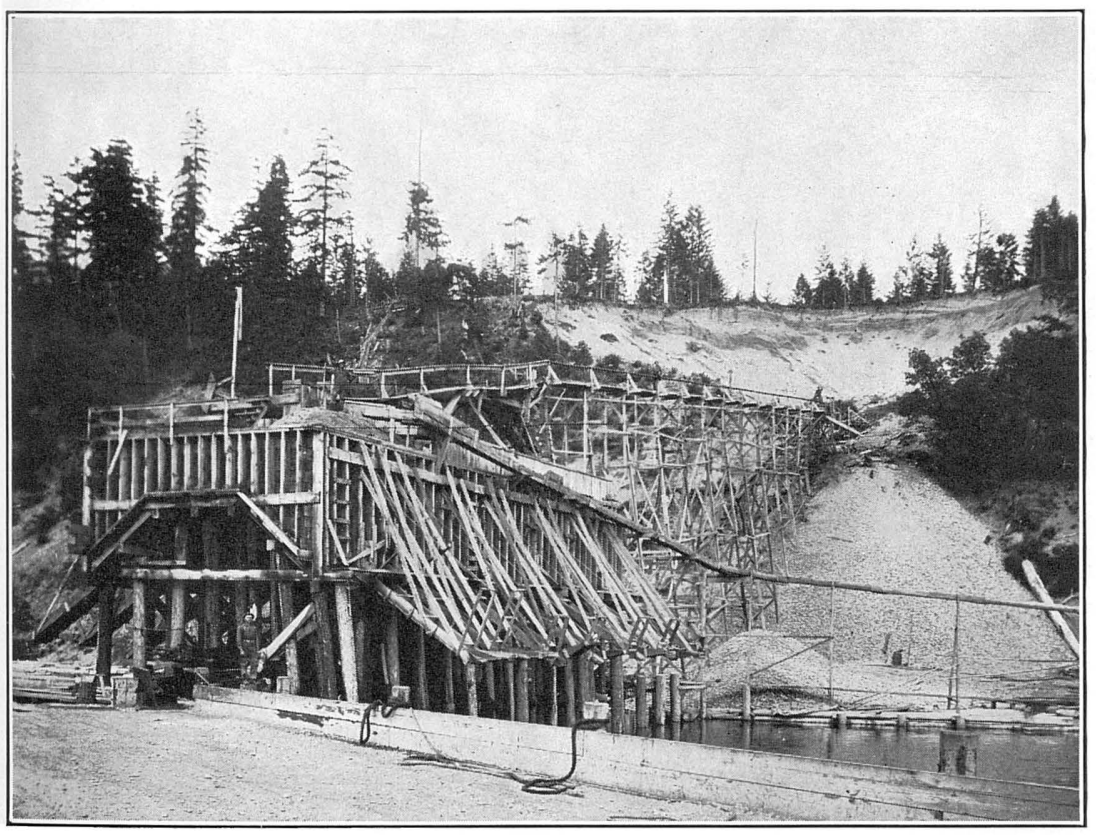

B. GRAVEL PIT, SCREENS, WASHER, AND BINS, STEILACOOM, WASH. 

Stevens County.-Extensive bodies of marble and limestone occur in Stevens County, mostly north of latitude $48^{\circ}$. At the south the rock is in isolated masses among granites, quartzites, and other rocks, but farther north the deposits increase in extent, and near the northern edge of the county the limestone occupies a large area. In the southern part of the area the rock appears in the valleys or foothills, while to the north it is in the high slopes. Much so-called marble occurs along the foothills and ridges bordering Colville Valley from about Valley Brook northward, but it is dolomite or magnesite. The deposits about Valley and Chewelah are highly magnesian, and some of them are nearly pure carbonate of magnesia.

Some of the marble deposits in the Colville region consist of 94 to 99 per cent of carbonate of lime and but little carbonate of magnesia. One of them is worked by the Jefferson Company in quarries 15 miles northeast of Colville. The deposits are very large, and the rock varies in color from dark blue to white.

Analyses of marbles at Jefferson quarries, northeast of Colville, Wash.

\begin{tabular}{|c|c|c|}
\hline 8 & White. & Pinkish. \\
\hline 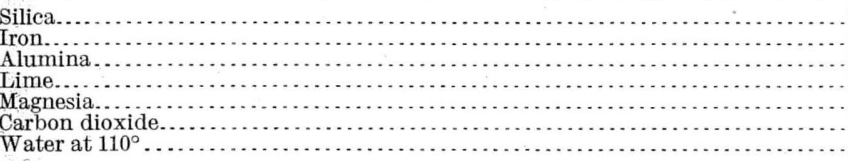 & $\begin{array}{r}0.87 \\
\text { None. } \\
\text { None. } \\
55.16 \\
.21 \\
43.77 \\
\text { None. }\end{array}$ & $\begin{array}{r}3.49 \\
.24 \\
\text { None. } \\
51.54 \\
1.11 \\
42.46 \\
.16\end{array}$ \\
\hline & 100.01 & 100.00 \\
\hline
\end{tabular}

The extensive marble deposits worked by the Crystal Marble Company about 7 miles southwest of Colville are dolomites containing over 20 per cent of magnesia.

The marbles of the Keystone Company are about 16. miles north and a little east of Colville, in the foothills of the western slope of the Pend Oreille Mountains and at the headwaters of Clugston Creek. The deposits are large and vary considerably in color, ranging from almost pure white to almost black. The marble shows but little stratification and trends almost due north and south. There is an alternation of shale, slate, limestone, and marble. The following analyses given by Shedd show the composition of the principal varieties:

Analyses of marbles 16 miles north of Colville, Wash.

\begin{tabular}{|c|c|c|c|}
\hline & White. & Gray. & $\begin{array}{l}\text { Dark } \\
\text { gray. }\end{array}$ \\
\hline \multirow{5}{*}{$\begin{array}{l}\text { Silica.......... } \\
\text { Ferric iron...... } \\
\text { Ferrous iron.... } \\
\text { Alumina........ } \\
\text { Lime........... } \\
\text { Magnesia.... } \\
\text { Carbon dioxide } \\
\text { Water ........... }\end{array}$} & $\begin{array}{r}0.98 \\
\text { Trace. }\end{array}$ & $\begin{array}{r}0.82 \\
\text { Trace. }\end{array}$ & $\begin{array}{r}1.89 \\
\text { Trace. }\end{array}$ \\
\hline & 53.96 & 54.81 & 42.60 \\
\hline & 1.25 & .70 & 10.05 \\
\hline & & & \\
\hline & 99.95 & 99.89 & 99.17 \\
\hline
\end{tabular}


These analyses show that the darker rock contains too much magnesia for cement manufacture. This is the case also with the marble at the Standard Company's properties in secs. 13 and 18, T. 35 N., Rs. 39 and 40 E., 4 miles east and a little south of Colville.

The marble deposit of the Colville Company is on the north fork of North Creek about 16 miles northeast of Colville and from 898 to 1,398 feet above the altitude of that town. Limestones, marbles, and 'slates alternate, but near the old mill site a drill hole 1,100 feet deep is said to have been in limestone for the entire distance. Shedd gives the following analyses of the marbles from this locality:

Analyses of marbles 16 miles northeast of Colville, Wash.

\begin{tabular}{|c|c|c|}
\hline . & White. & Dark gray. \\
\hline $\begin{array}{l}\text { Silica } \\
\text { Ferric iron } \\
\text { Ferrous iron }\end{array}$ & $\begin{array}{r}2.61 \\
\ldots \ldots \ldots \\
\cdots \ldots \ldots\end{array}$ & $\begin{array}{r}3.12 \\
.12 \\
.81\end{array}$ \\
\hline Alumina & & \\
\hline Lime & 53.68 & 52.04 \\
\hline \multirow[t]{2}{*}{ 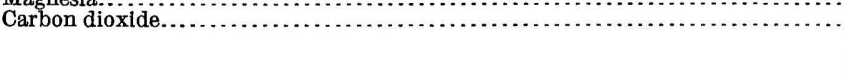 } & 42.89 & 43.22 \\
\hline & 99.94 & 99.98 \\
\hline
\end{tabular}

These analyses show that the rocks are high-grade limestones, containing but little magnesia and a very moderate amount of silica.

Several deposits of marble occur in sec. 13, T. 38, R. 37, 2 miles or more west of Bossburg in the slopes west of Columbia River. They are from 600 to 800 feet above the river. The beds are distinctly stratified and lie nearly horizontal. According to Shedd, they vary considerably in their composition, ranging from dolomite to nearly pure limestone. One analysis showed over 99 per cent of carbonate of lime with about 0.5 per cent of magnesia, but in other analyses of the pure-white rock the magnesia ran as high as 18.56 per cent.

The marble appears again in a bluff a mile north of Ryan, the next station north of Bossburg, and in similar bluffs on the opposite side of Columbia River. An analysis given by Shedd shows nearly 96 per cent of carbonate of lime, 1.6 per cent of magnesia, and 1 per cent of silica. Further exposures of the marble occur beyond Marble Station in secs. 22 and 27, T. 39 N., R. 39 E., on the east bank of the river. The deposits show some remains of stratification. Much of the rock is corvered by gravel and sand 6 to 14 feet thick, but in places it rises in bluffs 10 to 30 feet high. In most portions of the region in which these marbles occur there are extensive deposits of clay and large bodies of shale or schist suitable for cement manufacture.

At Box Canyon, on Pend Oreille River, there are large deposits of very high grade limestone and also argillaceous limestone, both suitable for cement manufacture. Extensive deposits of clay also 
are available. The Pacific Portland Cement Company, which has been organized to manufacture cement at this locality, plans to utilize a water power developed by damming Cedar Creek. The plant is 45 miles from Newport, on the Great Northern Railway, but the place can be reached by river transportation.

Analyses of limestone and clay from Box Canyon, Washington.

\begin{tabular}{|c|c|c|}
\hline & Limestone. & Clay. \\
\hline 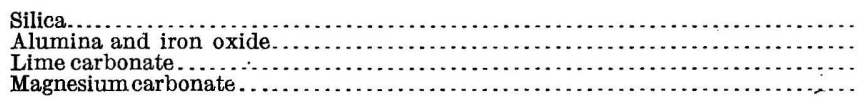 & $\begin{array}{r}1.6 \\
\text { Trace. } \\
98.5 \\
\text { Trace. }\end{array}$ & $\begin{array}{r}64.1 \\
22.3 \\
1.7 \\
\text { Trace. }\end{array}$ \\
\hline
\end{tabular}

Skagit County.-A thick mass of white crystalline limestone is included in the metamorphic series on the east side of Baker River, about three-fourths mile from the junction of that stream with Skagit River. The rock lies against slate, and the beds dip to the southwest at an angle of about $55^{\circ}$. The outcrop is nearly one-eighth mile long and averages 160 feet wide. It extends still farther underground and will afford a very large supply. It is now being worked extensively by a cement plant. Associated with the limestone is a clay which is utilized in the cement manufacture. This clay is a river deposit of considerable extent and thickness lying on a bed of gravel and abutting against the rock slopes of the sides of the valley. It is stratified, relatively uniform in character, and of light-blue color. The exposure is one-fourth mile in length, and the deposit was found to average 165 feet thick. The following analyses of the materials at the cement plant are given by Landes:

Analyses of limestone and clay at Washington Cement Works, Concrete, Wash.

\begin{tabular}{|c|c|c|c|c|}
\hline \multirow{2}{*}{ 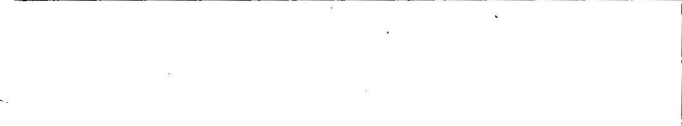 } & \multicolumn{2}{|c|}{ Limestone. } & \multicolumn{2}{|c|}{ Clay. } \\
\hline & 1. & 2. & 3. & 4. \\
\hline 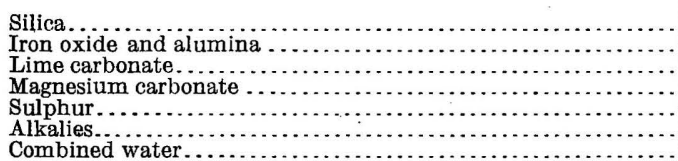 & $\begin{array}{r}0.80 \\
.70 \\
98.14 \\
.65 \\
\cdots\end{array}$ & $\begin{array}{r}3.41 \\
1.78 \\
92.50 \\
2.30\end{array}$ & $\begin{array}{r}58.75 \\
29.94 \\
4.66 \\
4.47 \\
\text { 1. } 48 \\
4.60\end{array}$ & $\begin{array}{r}55.90 \\
25.50 \\
4.90 \\
2.83 \\
.51 \\
3.91 \\
6.45\end{array}$ \\
\hline
\end{tabular}

Analyses Nos. 1 and 3 were made by C. W. Johnson, and Nos. 2 and 4 by F. C. Newton, both of Seattle, Wash.

Whatcom County.-Limestone occurs at a number of localities in the vicinity of Kendall, on the line of the Bellingham Bay and British Columbia Railway. North of the railroad at a point about 3 miles from Kendall there is a high h bluff of white marble which is conspicuous for some distance. It is included in an extensive metamorphic 
series of slates and other rocks, which is greatly folded and crushed, and, owing to its disturbed condition, the amount of rock available is not apparent. Several smaller outcrops appear south of the railroad. A few miles west of the limestone and along the railroad are beds of glacial clay known to be at least 50 feet thick, and this or the slate could be used with the limestone in making cement. The following are analyses of these materials:

Analyses of limestone, clay, and slate from Kendall, Wash.

\begin{tabular}{|c|c|c|c|c|c|c|}
\hline \multirow{2}{*}{. } & \multicolumn{2}{|c|}{ Limestone. } & \multicolumn{2}{|c|}{ Clay } & \multicolumn{2}{|c|}{ Slate. } \\
\hline & 1. & 2. & 3. & 4. & 5. & 6. \\
\hline 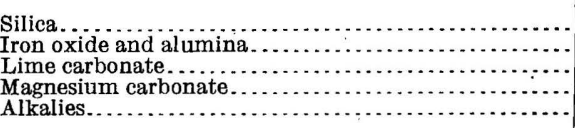 & $\begin{array}{r}1.52 \\
.35 \\
97.48 \\
1.26\end{array}$ & $\begin{array}{r}1.37 \\
98.72 \\
.26 \\
26\end{array}$ & $\begin{array}{r}61.27 \\
25.30 \\
2.96 \\
4.68\end{array}$ & $\begin{array}{r}57.06 \\
26.80 \\
10.62 \\
1.13 \\
2.56\end{array}$ & $\begin{array}{r}66.01 \\
17.65 \\
8.01 \\
3.15 \\
-\end{array}$ & $\begin{array}{r}72.69 \\
22.19 \\
2.16 \\
2.47\end{array}$ \\
\hline
\end{tabular}

1 and 3, D. W. Riedle, analyst; 2, 4, 5, and 6, A. H. Cederberg, analyst.

Ferry County.-The principal rocks in Ferry County consist of a metamorphic series of limestones, slates, and quartzites cut by granites and other igneous rocks. The largest limestone deposit occupies a narrow belt extending north and south across the county along the west fork of the granite divide which separates Columbia and Kettle rivers from the drainage to the west. A large outcrop a few miles west of Columbia is worked for a limekiln which produces high-grade lime. The rock is of bluish color, compact, and hard. Near by are clays and impure limestones which could be utilized for manufacture of cement. The following analyses of these materials are by A. H. Cederberg:

Analyses of limestones and clay near Republic, Wash.

\begin{tabular}{|c|c|c|c|c|}
\hline$\cdot$ & . & Marble. & $\begin{array}{c}\text { Impure } \\
\text { limestone. }\end{array}$ & Clay. \\
\hline $\begin{array}{l}\text { Silica } \\
\text { Alumina and iron oxide } \\
\text { Lime carbonate........ } \\
\text { Magnesium carbonate.. } \\
\text { Sulphur................ } \\
\text { Alkalies ............... }\end{array}$ & 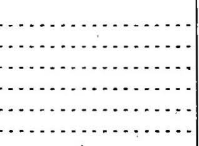 & $\begin{array}{r}1.1 \\
\text { Trace. } \\
98.6 \\
\text { Trace. } \\
\hdashline\end{array}$ & $\begin{array}{r}18.9 \\
7.2 \\
66.1 \\
4.5 \\
\text { Trace. } \\
.21\end{array}$ & $\begin{array}{r}60.13 \\
29.10 \\
8.98 \\
1.36 \\
.75 \\
.29\end{array}$ \\
\hline
\end{tabular}

Snohomish County.-Crystalline limestone occurs at a number of places in the eastern half of Snohomish County as a member of an extensive metamorphic series. It has been quarried at a point on the Everett and Monte Cristo Railway 3 miles east of Granite Falls; part of it has been used in the smelter at Everett and part burned into lime. The following analyses by A. H. Cederberg show the character of the rock and of associated calcareous slate and clay which could be used in manufacture of cement: 
Analyses of limestone, calcareous slate, and clay near Granite Falls, Wash.

\begin{tabular}{|c|c|c|c|c|}
\hline . & & $\begin{array}{l}\text { Lime- } \\
\text { stone. }\end{array}$ & Slate. & Clay. \\
\hline 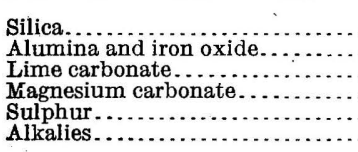 & $\begin{array}{l}{ } \\
{ } \\
{ }_{1}\end{array}$ & $\begin{array}{r}0.2 \\
1.4 \\
98.1 \\
\text { Trace. } \\
\end{array}$ & $\begin{array}{r}22.1 \\
10.6 \\
59.6 \\
1.8 \\
\text { Trace. } \\
1.4\end{array}$ & $\begin{array}{r}61.6 \\
25.4 \\
7.2 \\
2.3 \\
1.6 \\
2.9\end{array}$ \\
\hline
\end{tabular}

King County.--Crystalline limestones constitute a portion of the metamorphic series of King County, but very little information is available concerning them. Outcrops are known in the vicinity of Snoqualmie Pass and at several points along the Great Northern Railway, notably in the region about Baring. A large amount of clay occurs in the county, mainly in the coal measures at Renton, Taylor, Kummer, and other places, but no clays have yet been found near the limestone. Doubtless, however, some of the associated schists could furnish the argillaceous components necessary for cement manufacture.

Okanogan County.-A large amount of crystalline limestone occurs in the metamorphic series in the northern portion of this county. The largest areas are west and northwest of Riverside, where some of the outcrops rise in conspicuous cliffs. One of these is on the east slope of Palmer Mountain, where the rock is light gray in color and only partly crystalline. No analyses are available.

Pacific County.-Limestone has been reported from several localities in this county, but apparently the deposits are not of sufficiently large size to be of importance. The principal rocks are of Tertiary age, consisting mainly of shale. Some of the beds carry concretions of nearly pure carbonate of lime and others consist of an admixture of clay and carbonate of lime in varying proportions. Lime concretions have been collected and burned for lime near Knappton, but they are too widely scattered in the shale to furnish a large supply. On Bear-River, 6 miles east of Ilwaco, a mass of limestone appears on a small knoll rising a few feet above the tide marsh. The exposure is small, but owing to the covering the total extent of the deposit could not be ascertained; it contains fossils which appear to be of Eocene age. The following analysis is by S. V. Peppel, of Columbus, Ohio:

Analysis of limestone from Lindsey claim, Pacific County, Wash.

Silica.

Alumina

Iron oxides

.76

Lime carbonate

Magnesium carbonate 
Limestone concretions and very impure limestones are included in the Tertiary shale series in the ridge east of Bear River, and a claim has been staked on them at a point about 7 miles east of Ilwaco. The writer made an examination of this locality, and found that the impure limestone is in ledges presenting a thickness of about 30 feet. The concretions, which are much purer, vary from a few inches to 6 feet in diameter and are scattered through the overlying shale. The following analyses, furnished by $\mathrm{D}$. W. Riedle, of Portland, were made by E. C. Morse, of the Garrin Cyanide Company, Portland:

Partial analyses of limestones from Riedle claim east of Ilwaco, Wash.

\begin{tabular}{|c|c|c|}
\hline. & $\begin{array}{l}\text { Lime- } \\
\text { stone. }\end{array}$ & $\begin{array}{c}\text { Concretions } \\
\text { in shale. }\end{array}$ \\
\hline $\begin{array}{l}\text { Lime carbonate } \\
\text { Silica } \\
\text { Alumina }\end{array}$ & $\begin{array}{r}27.46 \\
34.54 \\
13.66\end{array}$ & $\begin{array}{r}44.28 \\
12.76 \\
4.20\end{array}$ \\
\hline
\end{tabular}

It will be seen from this analysis that the limestone is too impure to be used for cement unless the carbonate of lime constituent could be brought up to a much higher percentage by admixture with purer limestone.

Kittitas County.-In western Kittitas County small lenses of limestone are included in the Peshastin formation, which outcrops on the mountain slopes 10 to 15 miles southeast of Easton, on the Northern Pacific Railway near the head of North Fork of Taneum Creek and South Fork of Manastash Creek. They are too small and too far from lines of transportation to be of value.

Chelan County.-In the high mountain ridges of southern Chelan County are areas of Peshastin formation which carry small lenses of limestone, but they are too small to be of value.

\section{LTMESTONE IN OREGON.}

Occurrences of limestone in Oregon are widely separated, but deposits of large size are found in the southwestern and northeastern portions of the State. (See Pl. IX.) When geologic investigations are more widely extended doubtless many bodies of limestone will be brought to light and additional data obtained regarding deposits now known. In nearly all the areas where limestones are reported there are abundant supplies of clay or shale which could be used in making cement. Fuel, however, is scarce except neear the coast, where low-priced oil from southern California is available.

Jackson County. - Limestones occur at varions localities near Goldhill station on Rogue River, and some of them have been burned for lime for local supply and also shipped to Portland. A small amount has been used for flux in the smelter at Portland. The rock is in 


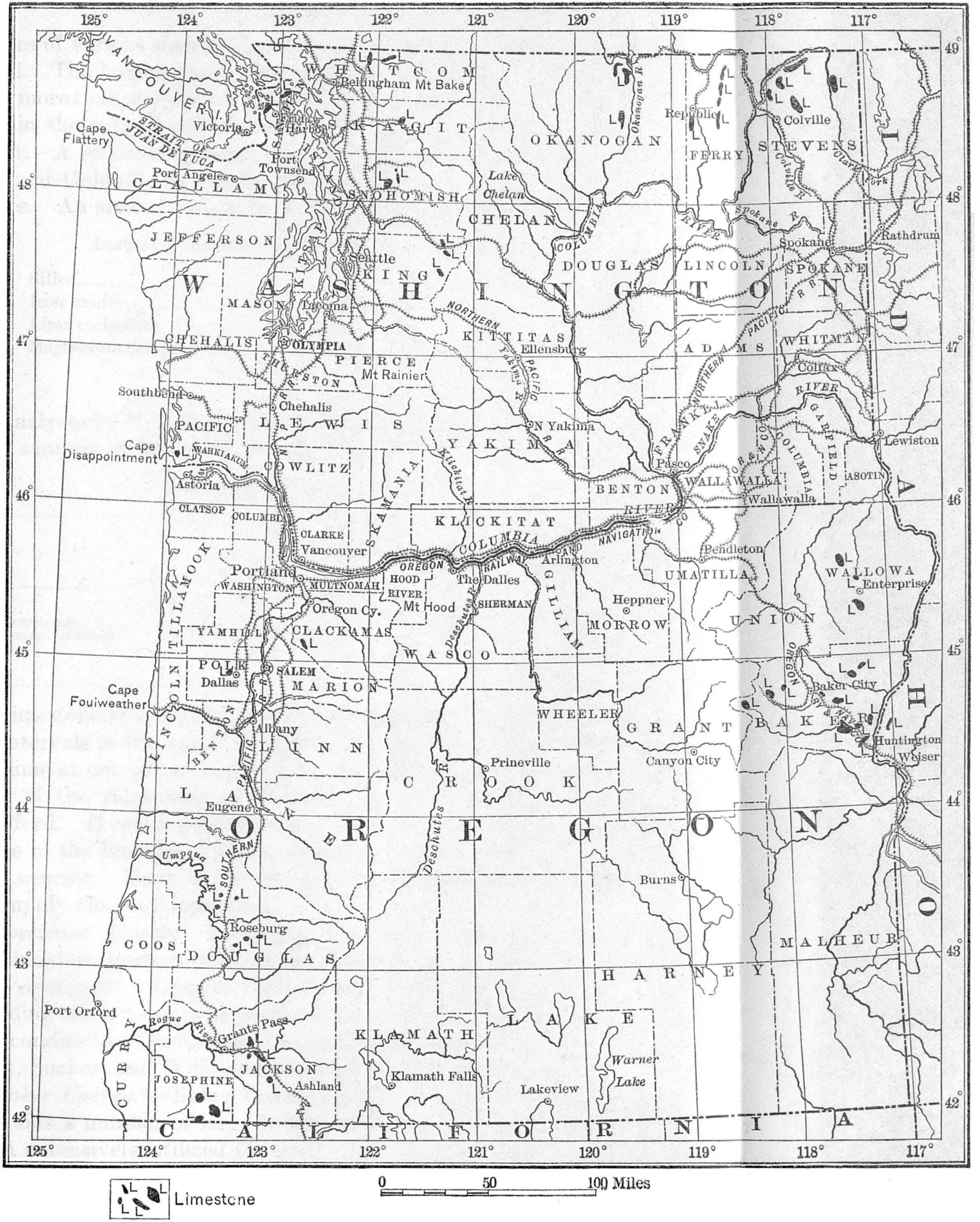

MAP OF WASHINGTON AND OREGON, SHOWING DISTRIBUTION OF LIMESTONE. 

lenses of various sizes included in schist dipping steeply to the northwest. The largest mass, about $1 \frac{1}{2}$ miles southwest of the station, is not more than 200 yards long and 30 feet thick. Other smaller masses are in the ridge north of the station and in the slopes south of the river. A moderately large deposit appears near Rockpoint, 3 miles west of Goldhill, on the north side of Rogue River. It is cut by dikes. An analysis made by J. S. Phillips is as follows:

$$
\text { Analysis of limestone from Rockpoint, west of Goldhill, Oreg. }
$$

Silica

Iron oxide.

Lime carbonate

Magnesium carbonate

100.0

Analyses by P. H. Bates, of the United States Geological Survey, of two samples of limestone obtained near Goldhill are as follows:

Analyses of limestones near Goldhill, Oreg.

\begin{tabular}{|c|c|c|}
\hline & $\begin{array}{c}1 \text { mile } \\
\text { northwest } \\
\text { of Goldhill. }\end{array}$ & $\begin{array}{l}\frac{1}{4} \text { mile } \\
\text { west of } \\
\text { Goldhill. }\end{array}$ \\
\hline \multirow{2}{*}{ 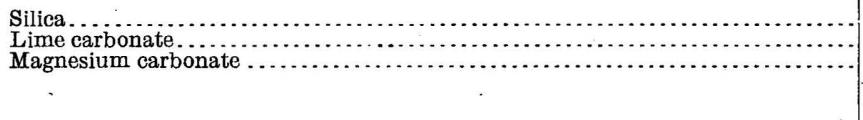 } & $\begin{array}{r}0.92 \\
98.22 \\
.84\end{array}$ & $\begin{array}{r}25.21 \\
69.82 \\
1.30\end{array}$ \\
\hline & 99. 98 & 96.33 \\
\hline
\end{tabular}

Limestone of similar character and conditions of occurence appears at intervals in the valley of Applegate Creek, and it has been burned for lime at one or two points. It also appears in small bodies on the foot of the ridge west of Phoenix, or about 5 miles southeast of Medford. If coal is produced from the mines near Medford, doubtless some of the limestones above described could be made economically into cement. Much of the schist probably is of suitable composition to supply the clay ingredient.

Josephine County.-Limestone occurs in large deposits in the southeastern portion of Josephine County and it is in this rock that the celebrated "Oregon Caves" are developed. Some lime and building stone have been produced, but no data are on record as to the conditions of occurrence or composition of the deposits. Steamboat, Sucker, and Williams creeks are the principal localities.

Baker County. ${ }^{a}$-Baker County, which is in northeastern Oregon, contains a number of large bodies of limestone, some of which have been extensively utilized for lime. One thick deposit crosses Burnt River canyon 3 miles above Huntington. The beds are several

$a$ The rocks of a portion of this county have been described by Waldemar Lindgren, in Twenty-second Ann. Rept. U. S. Geol. Survey, pt. 2, pp. 551-776. 
hundred feet across and upturned so that they dip to the northwest at a high angle. They are exposed in large quarries on the east side of the river and thence extend eastward for some distance across the high ridge between Burnt and Snake rivers, but do not appear to reach the latter river. Another thick mass of similar limestone outcrops west of Conner Creek 15 miles north of Huntington. The limestone quarried near Huntington is remarkably pure, carrying less than 1 per cent of silica, alumina, and iron. It lies in a series of shales, which appear to be suitable for admixture in cement manufacture.

A body of limestone with croppings several hundred feet wide extends along the ridge south of Burnt River 6 miles southwest of Durkee and smaller masses occur a short distance south and east of the larger one. Another small mass appears in the east bank of Burnt River 3 miles below Durkee. Two small outcrops are known 2 miles northeast of Pleasant Valley and another occurs 3 miles southeast of Baker. These all appear to be small lenses.

A large amount of limestone is included in the Triassic series on Eagle Creek, especially on its east branch, about 25 miles northeast of Baker. The following description is from Lindgren's report: ${ }^{a}$,

Limestone and black slate in small croppings were noted a short distance north of the Dolly Varden mine on the road from Sparta to Lily White. Similar rocks were noted 2 miles west of Sanger, at the Sanger mine, and at Lily White. On the road from the latter place to Cornucopia gray, soft, calcareous shale and limestone, with northerly strike, crop near the crossing of Eagle Creek, and the bluff at the bridge shows nearly horizontal gray limestone and calcareous shale, but little altered, in strata from 1 to 10 feet thick. The road continues up Paddy Creek, and limestone with uncertain dip is seen in places up to 800 feet above Eagle Creek, where it is covered by red and green shale and volcanic breccia of the same colors, containing fragments of old lavas and quartz diorites. The dip is here probably $10^{\circ} \mathrm{N}$., and these rocks continue for a mile or two until the basaltic area is entered a short distance beyond Little Eagle Creek. On the high slopes above, toward Paddys Paradise, strong croppings of limestone are seen.

Between the junction of the forks and Miles Camp, 2 miles below, the series is well exposed in mostly horizontal beds, sometimes faulted and in places containing strata of interbedded volcanic rocks. Half a mile below the junction is a high bluff on the east side, which at its base shows horizontal strata of calcareous shale and limestone. Two hundred feet above the creek the strata dip $20^{\circ}$ to $30^{\circ}$ E. and contain abundant Halobia shells and fragments of ammonites. Above the junction, on the east fork, bluish-gray limestone appears in heavy beds and continues in bluffs on both sides of the creek for half a mile. Three miles above the junction heavy limestone bluffs appear on the west side and the rock contains pentagonal crinoid stems and spines of echinoids. Interbedded with this limestone is a volcanic breccia of red and green colors, containing fragments of various lavas as well as of a quartz diorite. From here on the limestone gradually becomes more crystalline. The trend of the strata is $\mathrm{N} .10^{\circ}$. E. and the dip probably east, though it is difficult to determine exactly. The highest point reached was about 7 miles from the junction, where, at an elevation of 4,500 feet, an important creek comes in from the west. Above this place 
the canyon, which has been open with sloping benches in the bottom, becomes narrower, and the mountains rise several thousand feet on both sides. On the west side an enormous white sugar loaf of highly crystalline limestone, containing prisms of tremolite, reaches an elevation of about 6,000 feet. On the east the slopes are a little more gentle, but the mountains are much higher and consist of heavy masses of dark-green amphibolitic schist, showing, high up on the declivities, huge, interbedded, lenticular masses of gray limestone. The strike of the schistosity and also of the bedding is N. $20^{\circ} \mathrm{E}$.; the dip $60^{\circ} \mathrm{E}$. This schist is the volcanic breccia mentioned above, and has been compressed and made schistose by regional metamorphism. The transition from a series of altered limestone, shale, and volcanic breccias to schists and crystalline limestone is exceedingly beautiful and instructive. The change is rapid and yet gradual. High up at the head of the creek sharp limestone pinnacles rise to elevations of 8,000 feet; granitic rocks are probably entirely absent, though bowlders of this rock were noted in a gulch joining Eagle Creek 5 miles ąbove the junction. A passable wagon road leads up the east fork from lily White as far as 7 miles above the junction.

An outcrop of crystalline limestone of good quality occurs in the argillite half a mile north of Sumpter. It could not be traced far either way in the direction of the strike of the rocks, but it may be continuous for a greater distance than is apparent, as the rocks on the hillside are not well exposed. The outcrop is 10 to 15 feet across, and a small quantity was quarried for a smelter that was in operation for a short time during 1900 .

At Winterville, 40 miles southwest of Sumpter, a stratum of limestone 300 feet thick outcrops close by the placer diggings. It strikes N. $70^{\circ} \mathrm{W}$.

In the Copper Butte mining district, 18 miles northwest of Bakër City, several masses of limestone occur, which are described by Lindgren as follows:

One of the largest of them outcrops a mile northwest of Table Mountain, and is called the Big Lime dike. It is at least 600 feet long and 100 feet wide. Smaller masses are found 1 and 2 miles north of Medical Springs; others at the mine of the North American Copper Company and near Gilkeson's ranch. Many of them appear entirely bedded in greenstone. The limestone is not greatly altered. The stratification is not well defined, but it is believed that it has a moderate dip and a northwesterly strike.

In the Snake River canyon below the mouth of Cedar Creek southwest of the Seven Devils, 80 miles from Baker, the older rocks appear from under the lava and among them are bluish-gray limestones of supposed Triassic age. "On the Kleinschmidt grade 2 miles west of Huntley's ranch limestone and shale crop with northerly strike at an elevation of 3,800 feet; more limestone is found northwest of this place in Lime Peak Gulch;" finally, a heavy mass of limestone crosses Snake River between Spring Gulch and Eckles Bar.

Polk County.-About 3 miles west of Dallas are extensive exposures of an impure limestone which is quarried for building stone. It is claimed to be a natural cement rock. According to an analysis 
made in the Agricultural College of Michigan, its composition is as follows: Analysis of "cement rock" from 3 miles west of Dallas, Oreg.

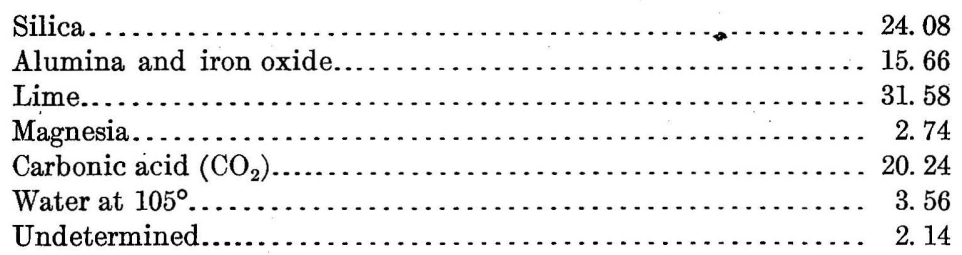

Douglas County.-In the sandstones and shales of the Shasta series ("Myrtle formation") south and southeast of Roseburg are a number of lens-shaped masses of limestone, which Diller ${ }^{a}$ has designated the Whitsett limestone lentils. They occur at intervals along the ridge and slopes extending northeast from Umpqua River nearly to the head of the north fork of Deer Creek. The limestone is a massive gray rock, and as it has yielded satisfactory lime at several localities it is probably of good quality. The southwesternmost occurrence is in sec. 30 , T. 28 N., R. $5 \mathrm{~W}$., near the top of a prominent ridge; the rock is traceable for only about 100 yards, with a width of 30 to 40 feet, so the supply is not great. The next exposure, a mile northeast, in secs. 20 and 29, shows a much larger body of the limestone rising in prominent ledges with the beds dipping northwest at an angle of $70^{\circ}$. The next body, which is mostly in sec. 14 of the same township, is somewhat smaller, but shows a thickness of 60 feet. Two small bodies occur on the south and north forks of Deer Creek in the next township northeast (T. 29 N., R. 4 W.); they are so compact that they are regarded as marble and have been quarried to some extent for that material. The last mass to the northeast is only 15 feet thick.

Near Oakland there are three small masses of impure limestone which have been regarded as cement rock. One is by the road nearly a mile northeast of Oakland, another at the head of Green Valley, 6 miles northwest of Oakland, and the third on Starr's ranch about 4 miles northeast of Umpqua Ferry. The areas are less than an acre in extent. Near Oakland the rock is a bluish shaly limestone that falls to pieces rather readily on exposure. It contains, besides a few fossils, brownish veins and nodules of various sizes up to 4 feet in diameter. At Starr's ranch the limestone is full of broken shells and the beds dip gently to the northwest. Some of the limestone from this region was quarried several years ago and taken to Oregon City to be tested as a cement material, but the results were not reported. 
Some deposits of tuff a few miles northeast of Wilbur have been claimed to be a natural cement rock, but no authentic tests are known. The material occurs in bodies of considerable size, but not well exposed. An analysis is as follows:

$$
\text { Analysis of tuff near Wilbur, Oreg. }
$$

Silica $\left(\mathrm{SiO}_{2}\right)$

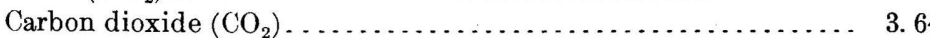

Alumina, titanium oxide, and phosphoric acid............ 9.75

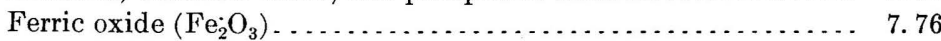

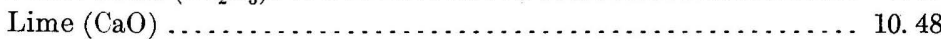

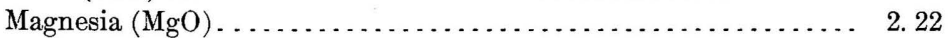

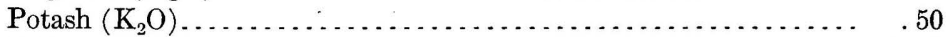

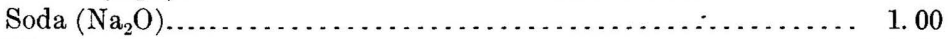

Water......................................... 9.29

99. 79

Clackamas County.-Five miles east of Monitor, a post-office in Marion County, is a ledge of impure limestone which has been traced at intervals for 12 miles. It has been burned into a natural cement, which it is claimed was used in the construction of the Oregon City Woolen Mills and in building the Coolidge block at Silverton. No analyses are given.

Wallowa County.-Very extensive deposits of limestone are reported in Wallowa County. At Lostine quarries produce rock which is burned into lime. The yearly production is about 1,000 bushels. Another kiln is at Joseph, and the rock is also reported at Fruita. No data are available as to the conditions of occurrence, extent, or composition, of these limestones.

80594--Bull. 387-09-3 



Lithomount

Pamphlet

Binders

Gaylord Bros. Inc.

Makers

Syracuse, N. Y. 
